Prepared in cooperation with the lowa Department of Natural Resources

\title{
Methods for Estimating Selected Spring and Fall Low-Flow Frequency Statistics for Ungaged Stream Sites in lowa, Based on Data through June 2014
}

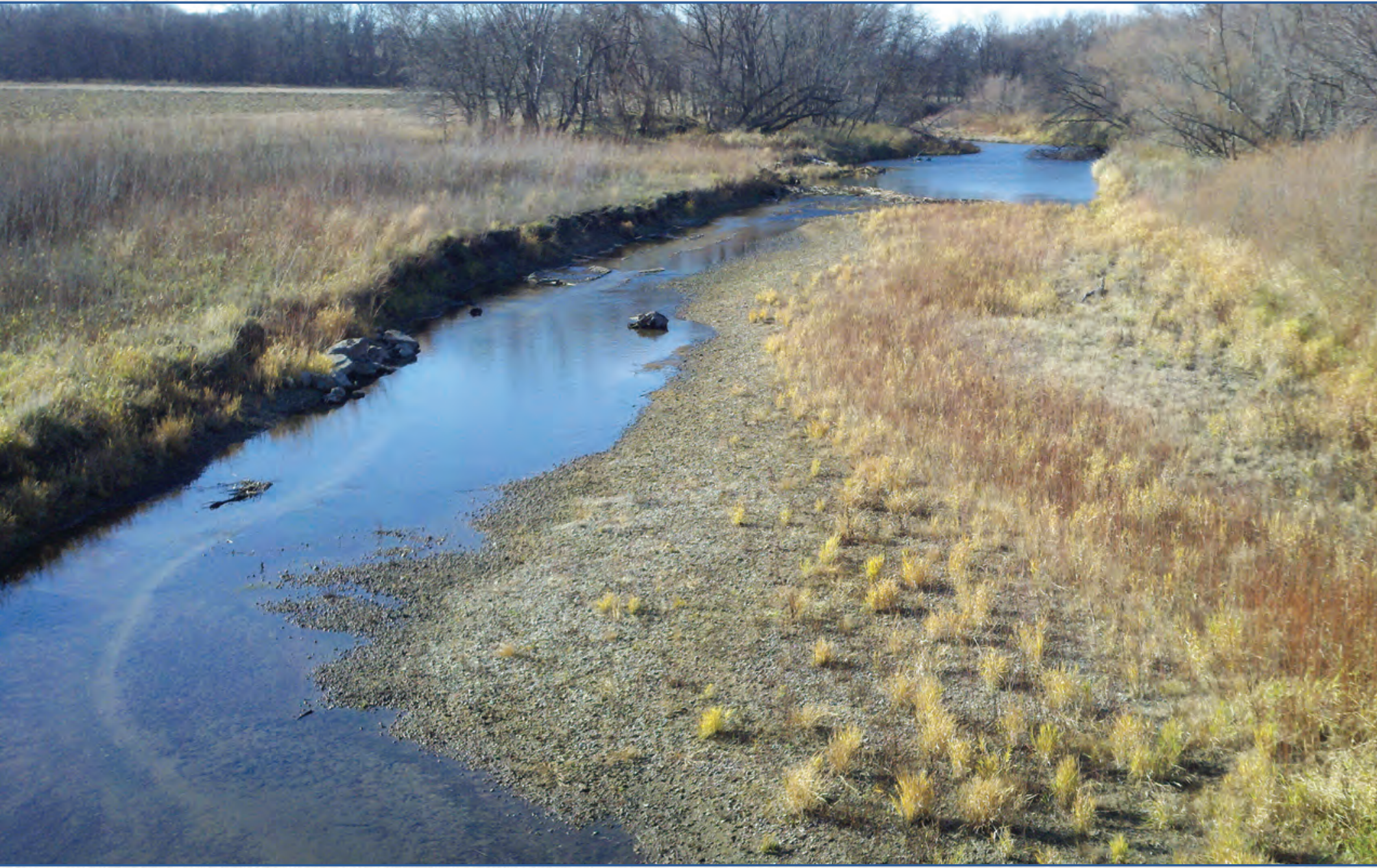

Scientific Investigations Report 2016-5111

Version 1.1, October 2016 
Cover. View looking upstream from streamgage South Fork lowa River northeast of New Providence (05451210), lowa. Photograph taken November 8, 2012, by U.S. Geological Survey. 


\section{Methods for Estimating Selected Spring and Fall Low-Flow Frequency Statistics for Ungaged Stream Sites in lowa, Based on Data through June 2014}

By David A. Eash, Kimberlee K. Barnes, and Padraic S. O'Shea

Prepared in cooperation with the lowa Department of Natural Resources

Scientific Investigations Report 2016-5111

Version 1.1, October 2016 


\title{
U.S. Department of the Interior SALLY JEWELL, Secretary
}

\section{U.S. Geological Survey Suzette M. Kimball, Director}

\author{
U.S. Geological Survey, Reston, Virginia: 2016 \\ First release: 2016 \\ Revised: October 2016 (ver 1.1)
}

\begin{abstract}
For more information on the USGS - the Federal source for science about the Earth, its natural and living resources, natural hazards, and the environment-visit http://www.usgs.gov or call 1-888-ASK-USGS.

For an overview of USGS information products, including maps, imagery, and publications, visit http://store.usgs.gov.
\end{abstract}

\footnotetext{
Any use of trade, firm, or product names is for descriptive purposes only and does not imply endorsement by the U.S. Government.

Although this information product, for the most part, is in the public domain, it also may contain copyrighted materials as noted in the text. Permission to reproduce copyrighted items must be secured from the copyright owner.

Suggested citation:

Eash, D.A., Barnes, K.K., and O'Shea, P.S., 2016, Methods for estimating selected spring and fall low-flow frequency statistics for ungaged stream sites in lowa, based on data through June 2014 (ver. 1.1, October 2016): U.S. Geological Survey Scientific Investigations Report 2016-5111, 32 p., http://dx.doi.org/10.3133/sir20165111.
}

ISSN 2328-0328 (online) 


\section{Contents}

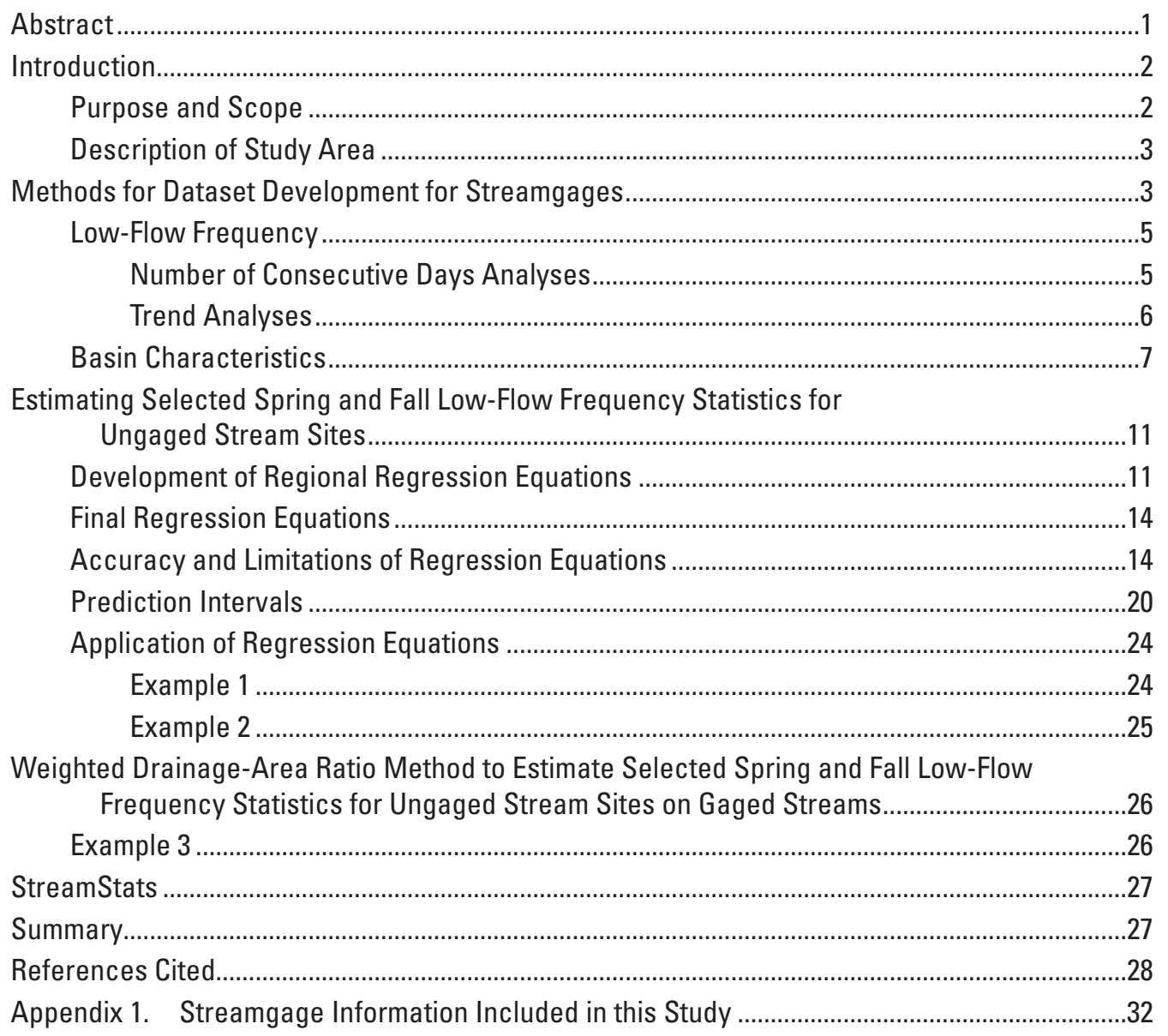

\section{Figures}

1. Map showing low-flow regions in lowa and streamgages included in this study............4

2. Screenshot of the weighted-multiple-linear regression program smoothing function for generalized-least-squares correlation of the time series of annual spring (April through June) minimum 7-day mean flows as a function of distance between 62 streamgages in the northeast region with 30 years of concurrent flow.

3. Graphs showing relation between the spring 7-day mean low-flow for a recurrence interval of 10 years discharges computed from observed streamflow and those predicted from regression equations for low-flow regions in lowa for northeast region, northwest region, and southern region, showing streamgages by map number with some of the largest differences between predicted and observed discharges. 
4. Graphs showing relation between the fall 7-day mean low-flow for a recurrence interval of 10 years discharges computed from observed streamflow and those predicted from regression equations for low-flow regions in lowa for northeast region, northwest region, and southern region, showing streamgages by map number with some of the largest differences between predicted and observed discharges

\section{Tables}

1. Basin characteristics tested for significance in developing regression equations .........8

2. Streamgages removed from the regression analyses.

3. Percentage of streamgages with estimates of zero flow computed from observed streamflow for selected spring and fall low-flow frequency statistics in each region of lowa

4. Regression equations for estimating selected spring and fall low-flow frequency statistics for unregulated streams in the northeast region of lowa.

5. Regression equations for estimating selected spring and fall low-flow frequency statistics for unregulated streams in the northwest region of lowa.

6. Regression equations for estimating selected spring and fall low-flow frequency statistics for unregulated streams in the southern region of lowa

7. Range of basin-characteristic values used to develop selected spring and fall low-flow frequency regression equations for unregulated streams in lowa

8. Values needed to determine the 90-percent prediction intervals for estimates obtained from regional regression equations using covariance matrices in lowa.........2

1-1. Selected spring and fall low-flow frequency statistics, and basin characteristics for streamgages shown in figure 1

\section{Conversion Factors}

U.S. customary units to International System of Units

\begin{tabular}{|c|c|c|}
\hline Multiply & By & To obtain \\
\hline \multicolumn{3}{|c|}{ Length } \\
\hline inch (in.) & 2.54 & centimeter $(\mathrm{cm})$ \\
\hline inch (in.) & 25.4 & millimeter $(\mathrm{mm})$ \\
\hline foot (ft) & 0.3048 & meter $(\mathrm{m})$ \\
\hline mile (mi) & 1.609 & kilometer (km) \\
\hline foot per mile (ft/mi) & 0.1894 & meter per kilometer $(\mathrm{m} / \mathrm{km})$ \\
\hline \multicolumn{3}{|c|}{ Area } \\
\hline square mile $\left(\mathrm{mi}^{2}\right)$ & 2.590 & square kilometer $\left(\mathrm{km}^{2}\right)$ \\
\hline mile per square mile $\left(\mathrm{mi} / \mathrm{mi}^{2}\right)$ & 0.621 & kilometer per square kilometer $\left(\mathrm{km} / \mathrm{km}^{2}\right)$ \\
\hline square mile per mile $\left(\mathrm{mi}^{2} / \mathrm{mi}\right)$ & 1.609 & square kilometer per kilometer $\left(\mathrm{km}^{2} / \mathrm{km}\right)$ \\
\hline \multicolumn{3}{|c|}{ Flow rate } \\
\hline cubic foot per second $\left(\mathrm{ft}^{3} / \mathrm{s}\right)$ & 0.02832 & cubic meter per second $\left(\mathrm{m}^{3} / \mathrm{s}\right)$ \\
\hline \multicolumn{3}{|c|}{ Hydraulic conductivity } \\
\hline inch per second (in/s) & 25,400 & micrometers per second $(\mu \mathrm{m} / \mathrm{s})$ \\
\hline
\end{tabular}




\section{Abbreviations}

BASINS Better Assessment Science Integrating Point and Nonpoint Sources

BSLDEM10M average basin slope computed from 10-meter digital elevation model

DAR drainage-area ratio

DEM digital elevation model

DRNAREA geographic information system drainage area

DRNFREO drainage frequency

GIS geographic information system

GLS generalized-least-squares

IDNR lowa Department of Natural Resources

LC11CRPHAY percent area of cultivated crops and hay from National Land Cover Database 2011 classes 81 and 82

In natural logarithm

$\log 10 \quad$ base 10 logarithm

M1D10Y0406 spring (April through June) 1-day mean low flow for a recurrence interval of 10 years

M1D10Y1012 fall (October through December) 1-day mean low flow for a recurrence interval of 10 years

M7D10Y annual 7-day mean low-flow for a recurrence interval of 10 years

M7D10Y0406 spring (April through June) 7-day mean low flow for a recurrence interval of 10 years

M7D10Y1012 fall (October through December) 7-day mean low flow for a recurrence interval of 10 years

M30D10Y46 spring (April through June) 30-day mean low flow for a recurrence interval of 10 years

M30D10Y0D fall (October through December) 30-day mean low flow for a recurrence interval of 10 years

MEV model error variance

$\mathrm{N}$-day number of consecutive days

NHD National Hydrography Dataset

NLCD National Land Cover Database

PRISM Parameter-elevation Regressions on Independent Slopes Model

PRJULDEC10 mean July through December precipitation 1981-2010

Pseudo- $R^{2} \quad$ pseudo coefficient of determination

RRE regional regression equation

SEE average standard error of estimate

SEM standard error of model 


$\begin{array}{ll}\text { SEP } & \text { average standard error of prediction } \\ \text { SSURGOA } & \text { hydrologic soil type A } \\ \text { SSURGOC } & \text { hydrologic soil type C } \\ \text { SSURGOD } & \text { hydrologic soil type D } \\ \text { USGS } & \text { U.S. Geological Survey } \\ \text { WBD } & \text { Watershed Boundary Dataset } \\ \text { WDAR } & \text { weighted drainage-area ratio } \\ \text { WLA } & \text { waste-load allocation } \\ \text { WLS } & \text { weighted-least-squares } \\ \text { WREG } & \text { weighted-multiple-linear regression program }\end{array}$




\title{
Methods for Estimating Selected Spring and Fall Low- Flow Frequency Statistics for Ungaged Stream Sites in lowa, Based on Data through June 2014
}

\author{
By David A. Eash, Kimberlee K. Barnes, and Padraic S. 0'Shea
}

\section{Abstract}

A statewide study was led to develop regression equations for estimating three selected spring and three selected fall low-flow frequency statistics for ungaged stream sites in Iowa. The estimation equations developed for the six low-flow frequency statistics include spring (April through June) 1-, 7-, and 30-day mean low flows for a recurrence interval of 10 years and fall (October through December) 1-, 7-, and 30-day mean low flows for a recurrence interval of 10 years. Estimates of the three selected spring statistics are provided for 241 U.S. Geological Survey continuousrecord streamgages, and estimates of the three selected fall statistics are provided for 238 of these streamgages, using data through June 2014. Because only 9 years of fall streamflow record were available, three streamgages included in the development of the spring regression equations were not included in the development of the fall regression equations. Because of regulation, diversion, or urbanization, 30 of the 241 streamgages were not included in the development of the regression equations. The study area includes Iowa and adjacent areas within 50 miles of the Iowa border. Because trend analyses indicated statistically significant positive trends when considering the period of record for most of the streamgages, the longest, most recent period of record without a significant trend was determined for each streamgage for use in the study. Geographic information system software was used to measure 63 selected basin characteristics for each of the 211 streamgages used to develop the regional regression equations. The study area was divided into three low-flow regions that were defined in a previous study for the development of regional regression equations.

Because several streamgages included in the development of regional regression equations have estimates of zero flow calculated from observed streamflow for selected spring and fall low-flow frequency statistics, the final equations for the three low-flow regions were developed using two types of regression analyses - left-censored and generalized-leastsquares regression analyses. A total of 211 streamgages were included in the development of nine spring regression equations - three equations for each of the three low-flow regions. A total of 208 streamgages were included in the development of nine fall regression equations - three equations for each of the three low-flow regions. A censoring threshold was used to develop 15 left-censored regression equations to estimate the three fall low-flow frequency statistics for each of the three low-flow regions and to estimate the three spring low-flow frequency statistics for the southern and northwest regions. For the northeast region, generalized-least-squares regression was used to develop three equations to estimate the three spring low-flow frequency statistics. For the northeast region, average standard errors of prediction range from 32.4 to 48.4 percent for the spring equations and average standard errors of estimate range from 56.4 to 73.8 percent for the fall equations. For the northwest region, average standard errors of estimate range from 58.9 to 62.1 percent for the spring equations and from 83.2 to 109.4 percent for the fall equations. For the southern region, average standard errors of estimate range from 43.2 to 64.0 percent for the spring equations and from 78.1 to 78.7 percent for the fall equations.

The regression equations are applicable only to stream sites in Iowa with low flows not substantially affected by regulation, diversion, or urbanization and with basin characteristics within the range of those used to develop the equations. The regression equations will be implemented within the U.S. Geological Survey StreamStats Web-based geographic information system application. StreamStats allows users to click on any ungaged stream site and compute estimates of the six selected spring and fall low-flow statistics; in addition, 90-percent prediction intervals and the measured basin characteristics for the ungaged site are provided. StreamStats also allows users to click on any Iowa streamgage to obtain computed estimates for the six selected spring and fall low-flow statistics. 


\section{Introduction}

Knowledge of the magnitude and frequency of low flows for streams is fundamental for water-supply planning and design; waste-load allocation (WLA); reservoir storage design and maintenance; and quantity and quality of water for irrigation, recreation, aquatic life, and wildlife conservation. Lowflow statistics indicate the probable availability of water in streams during times when conflicts between water supply and demand are most prevalent; therefore, low-flow statistics are needed by Federal, State, and local agencies for water-quality regulatory activities and water-supply planning and management. These statistics can be used as thresholds when setting wastewater-treatment plant effluent limits and allowable pollutant loads to meet water-quality regulations. Low-flow statistics can be used by commercial, industrial, and hydroelectric facilities to determine availability of water for water supply, wastewater discharge, and power generation. Low-flow statistics also can be used in ecological research. Low-flow conditions can disturb ecosystems and create biological responses and changes in habitat, such as reduced populations of aquatic species and shifts in the relative distribution of species (Miller and Golladay, 1996).

Currently (2016), 481 stream reaches in Iowa were designated as impaired (Category 5 of the State's Section 303[d] list that exceed specific water-quality criteria [Iowa Department of Natural Resources and the U.S. Environmental Protection Agency, 2015]). These stream reaches may require having pollutant loads analyzed and maximum loading rates established by total maximum daily load assessments (U.S. Environmental Protection Agency, 2015). Reliable estimates of expected streamflow are needed for specific periods of the year when determining the maximum allowable load of a pollutant in a stream. Estimates of expected streamflow are especially important for low-flow periods when agencies need to determine WLAs for National Pollution Discharge Elimination System discharge permits for municipalities, industries, and other entities with facilities that discharge wastewater into a stream. A WLA is the loading capacity or maximum quantity of a pollutant each point-source discharger is allowed to discharge into a particular stream. The WLAs are used to establish water-quality-based limits for point-source discharges.

Seasonal low-flow statistics are used by Iowa Department of Natural Resources (IDNR) for setting water-quality-based effluent limits for controlled discharge lagoons wastewatertreatment plants during April through June (spring) and October through December (fall). Because controlled discharge lagoons are only allowed to discharge twice a year, one in the spring and another in the fall, spring and fall low-flow statistics are needed to develop water-quality-based effluent limits for these facilities (Connie Dou, Iowa Department of Natural Resources, written commun., 2016).

In Iowa, the U.S. Geological Survey (USGS) operates a network of streamgages that provides streamflow data for a variety of purposes, and spring and fall low-flow frequency statistics can be calculated from streamflow data collected at these locations. Streamgages cannot be operated at every location; therefore, methods are needed for estimating spring and fall low-flow frequency statistics at ungaged stream sites. In 2015, the USGS led a statewide study in cooperation with the IDNR to update and improve the accuracy of estimates of spring and fall low-flow frequency statistics for ungaged stream sites in Iowa. Primary components of the study included (1) computing three selected spring low-flow frequency statistics at 241 streamgages and three selected fall low-flow frequency statistics at 238 streamgages using the longest, most recent period of streamflow record through June 2014 without a significant trend; (2) measuring 63 basin characteristics for each of the 208 streamgages included in the fall season regression analyses and for an additional 3 streamgages for a total of 211 streamgages included in the spring season regression analyses; and (3) developing 18 regional regression equations (RREs) to estimate the six selected statistics at ungaged stream sites based on basin characteristics. Because only 9 years of fall streamflow record were available, 3 streamgages included in the computation of the spring statistics and the development of the spring RREs were not included in the computation of the fall statistics and the development of the fall RREs.

\section{Purpose and Scope}

The RREs for estimating selected spring and fall lowflow frequency statistics were developed for use in Iowa and are described in this report. The regression equations relate selected spring and fall low-flow frequency statistics to physical and climatic characteristics of drainage basins. In addition, the regression equations developed from this study will be included in StreamStats, a USGS Web-based geographic information system (GIS) application (http://water. usgs.gov/osw/streamstats/). StreamStats allows users to obtain selected streamflow-statistic estimates, upstream drainagebasin characteristics, and other information for user-selected stream sites.

This report presents 18 RREs that can be used to estimate 6 selected statistics for ungaged sites on unregulated streams in Iowa. The equations can be used to estimate low-flow frequency statistics for spring (April through June) 1-, 7-, and 30-day mean low flows for a recurrence interval of 10 years and fall (October through December) 1-, 7-, and 30-day mean low flows for a recurrence interval of 10 years. The equations were developed using selected spring low-flow frequency statistics computed for 211 continuous-record streamgages and for selected fall low-flow frequency statistics computed for 208 of these streamgages. These streamgages are unaffected by regulation, diversion, or urbanization and they are in Iowa and in adjacent States within a 50-mile (mi) buffer of Iowa (all gaged drainage basins are within the buffer). Because only 9 years of fall streamflow record were available, 3 streamgages included in the development of the spring RREs 
were not included in the development of the fall RREs. Drainage areas of the streamgages used to develop the spring and fall RREs ranged from 1.4 to 7,785 square miles $\left(\mathrm{mi}^{2}\right)$.

Selected spring low-flow frequency statistics computed for 241 streamgages and selected fall low-flow frequency statistics computed for 238 of these streamgages are presented in this report. The spring and fall low-flow frequency statistics were computed using streamflow data collected through June 2014 at streamgages with at least 10 years of streamflow record. Spring and fall low-flow frequency statistics included in this report for 30 streamgages operated by the USGS Iowa Water Science Center were not included in the development of RREs because streamflow at these streamgages is affected by regulation, diversion, or urbanization. These 30 streamgages are listed in table 1-1 (of the appendix) under the column heading of "Low-flow region" with the abbreviation "NU" for streamgage not used in the development of RREs. Significant positive trends in annual low flow were indicated when considering the period of streamflow record for most of the streamgages included in this study. Therefore, spring and fall low-flow frequency statistics were computed for each streamgage using the longest, most recent period of record without a significant trend in low flow. The accuracy and limitations of the regression equations and the methodology used to develop the equations are described in the report.

This report is the fifth in a series of reports that describe low-flow characteristics for Iowa streams. Brief descriptions of the first three reports are presented in the fourth report (Eash and Barnes, 2012).

\section{Description of Study Area}

The study area includes Iowa and adjacent areas within 50 miles of the Iowa border in the neighboring States of Illinois, Minnesota, Missouri, Nebraska, South Dakota, and Wisconsin (fig. 1). A map of soil regions in Iowa is presented in Eash and Barnes (2012) and a detailed description of soils in Iowa is presented by Oschwald and others (1965). A brief description of landform regions in Iowa is presented in Eash and Barnes (2012) and a detailed description is presented by Prior (1991). Updates to landform regions in Iowa are described in Prior and others (2009).

Most precipitation in the study area results from storms moving inland primarily from the Gulf of Mexico (not shown) and secondarily from the Pacific Ocean (not shown) (Soenksen and Eash, 1991). Annual precipitation, which is mostly rain, ranges from 26 inches in the extreme northwest to as much as 38 inches in the southeast; the statewide average is around 34 inches (National Climatic Data Center, 2012). About 75 percent of the annual precipitation is received during April through September. During August through February, streamflow in most unregulated streams in the study area is typically base flow. During March through July, streamflow is substantially greater, primarily as a result of snowmelt during late February through early April and rainfall during May through July. Annual minimum streamflows are typically during August through February (Eash and others, 2015).

During the second one half of the 20th century, base flow in streams in Iowa has increased, and more precipitation flowed into streams as base flow than as surface flow (Schilling and Libra, 2003). Hypothesized reasons for the observed base-flow trends include (1) improved conservation practices, (2) added artificial drainage, (3) increasing row crop intensity, and (4) channel incision. Increasing base flow in Iowa streams is significantly related to increasing row crop production; a 13-52-percent increase in row crop percentage in many Iowa basins has contributed to a 7-31-percent increase in base flow (Schilling, 2005). Analyses of streamflow trends for the United States indicated positive trends in minimum flows and that the trends appear to have started abruptly around 1970 (McCabe and Wolock, 2002; Lins, 2005). Kendall's tau trend analyses, presented in Eash and Barnes (2012), of annual and fall low flows for 208 unregulated streamgages in Iowa (and within a 50-mi buffer of the State) indicated significant positive trends for 133 of the 208 streamgages tested for the period of record. Lins (2005) indicated positive trends in the Upper Mississippi region and that the pattern of trends is dominated by increases in streamflow during September through December. Small and others (2006) indicated that positive trends in 7-day low flow for the upper Mississippi region during 1948-97 appear to be related to an increase in fall precipitation.

\section{Methods for Dataset Development for Streamgages}

Data used in this report were collected for 241 selected active and inactive continuous-record streamgages in Iowa and within a 50-mi buffer of Iowa in the neighboring States of Illinois, Minnesota, Missouri, Nebraska, South Dakota, and Wisconsin (fig. 1; table1-1 of the appendix). Daily mean discharge data collected through June 2014 were retrieved for the 241 streamgages from the USGS National Water Information System database (U.S. Geological Survey, 2016) for use in computing selected spring and fall low-flow frequency statistics. Streamgages with at least 10 complete years of spring (April through June) or fall (October through December) daily mean discharges were selected for the computation of selected spring and fall low-flow frequency statistics. A subset of these streamgages that were unaffected by regulation, diversion, or urbanization were selected for evaluation in the study for the development of RREs.

Retrieved streamflow data were reviewed to eliminate data affected by regulation, diversion, or urbanization from biasing the development of regression equations for selected spring and fall low-flow frequency statistics. Decisions on inclusion or exclusion of data for streamgages were made using hydrologic judgment according to available information regarding the occurrence, timing, and extent of regulation, 


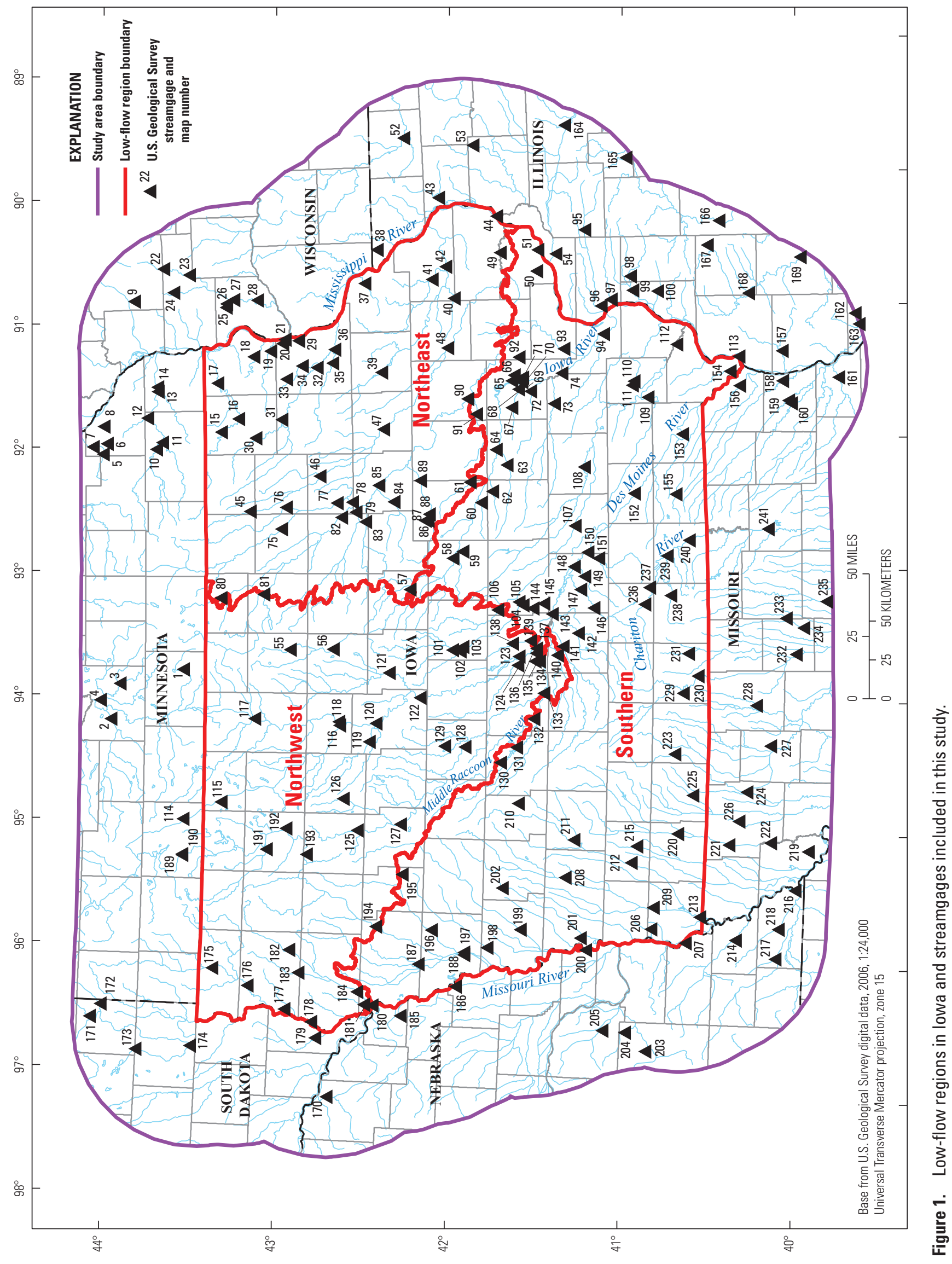


diversion, or urbanization upstream from the streamgages. In general, all streamgages with data affected by upstream regulation, diversion, or urbanization during typical low-flow periods were deleted from the regression study dataset. Information available about possible regulations, diversions, or urbanization at streamgages was not always complete, and the veracity was questionable in some cases. Thus, data affected by regulation, diversion, or urbanization possibly could have been included in the regression study dataset. However, the overall effect on the development of RREs is believed to be minimal.

Spring and fall low-flow frequency statistics included in this report for 30 streamgages operated by the USGS Iowa Water Science Center were not included in the development of RREs because streamflow at these streamgages is affected by regulation, diversion, or urbanization (table 1-1). Of the 211 streamgages included in the development of RREs in this study, 137 are in Iowa and 74 are in neighboring States. Streamgages from neighboring States were used to improve the representativeness of selected spring and fall low-flow frequency statistics and basin characteristics present in Iowa border areas and were used to provide better estimates of the error of the regression equations for ungaged sites near the State border.

Base-flow measurement data collected during 1957-1976 at 426 low-flow partial-record sites in Iowa (Lara, 1979) were not included in this study because of the possibility that data limited to 1957-76 may bias the development of RREs. A discussion of the reasons for not including the base-flow measurement data in the previous low-flow study for Iowa is presented in Eash and Barnes (2012).

\section{Low-Flow Frequency}

Low-flow frequencies were estimated for statistics during spring (April through June) 1-, 7-, or 30-day mean low flow for a recurrence interval of 10 years (M1D10Y0406, M7D10Y0406, and M30D10Y46, respectively) and during fall (October through December) 1-, 7-, or 30-day mean low flow for a recurrence interval of 10 years (M1D10Y1012, M7D10Y1012, and M30D10YOD, respectively). Names used to describe low-flow frequency statistics in this report were selected to maintain consistency with existing names used in StreamStats (http://streamstatsags.cr.usgs.gov/ss_defs/flow_ stat_defs.aspx).

Because 10-11 years of spring streamflow record and only 9 years of fall streamflow record were available for streamgages 05409830, 06480400, and 06903500 (map numbers 25, 171, and 237; fig. 1), spring low-flow frequency statistics were estimated for 241 streamgages and fall low-flow frequency statistics were estimated for 238 streamgages in this study (table 1-1). With the exclusion of 30 streamgages from the development of RREs because of regulation, diversion, or urbanization (table 1-1), 211 streamgages were used for the development of the spring RREs and 208 streamgages were used for the development of the fall RREs.

The magnitude and frequency of low flows are computed for a streamgage by relating a specific number of consecutive daily mean discharges during an annual period to annual minimum nonexceedance probability or recurrence interval. Annual nonexceedance probability is expressed as the chance that a selected low-flow magnitude will not be exceeded during any single year. Recurrence interval, which is the reciprocal of the annual nonexceedance probability, is the average number of years between nonexceedances of a selected lowflow magnitude.

For example, if a theoretical spring or fall 7-day mean low-flow discharge is not exceeded once on the average during any 10 -year period (recurrence interval), then the discharge has a 10-percent chance (annual nonexceedance probability equals 0.1 ) of not being exceeded during any single year. This spring or fall low-flow discharge is referred to as the annual spring or fall 7-day, mean low flow for a recurrence interval of 10 years (M7D10Y0406 or M7D10Y1012, respectively). Although the recurrence interval represents the long-term average period between spring or fall low flows of a specific magnitude, rare low flows could occur at shorter intervals or even within the same year during the spring or fall. Discharge values estimated for low-flow frequency statistics like M7D10Y0406 or M7D10Y1012 can change as streamflow periods of record become longer.

The USGS has established standard methods for estimating low-flow frequency statistics for streamgages (Riggs, 1972). Spring and fall low-flow frequency statistics included in this study were calculated using the USGS Surface-Water Toolbox computer program (Kate Flynn, U.S. Geological Survey, written commun., 2014) that implements the USGS Surface-Water Statistics computer program functionality (Flynn and others, 1995) within a modern Windows ${ }^{\mathrm{TM}}$ interface. Specifically, the "Integrated Frequency Analysis" procedure within the Surface-Water Toolbox computer program was used to calculate spring and fall low-flow frequency statistics for this study. This procedure for statistical analysis of timeseries data was obtained from the U.S. Environmental Protection Agency Better Assessment Science Integrating Point and Nonpoint Sources (BASINS) program (U.S. Environmental Protection Agency, 2013). The BASINS program is a multipurpose environmental analysis system designed for drainagebasin- and water-quality-based studies.

\section{Number of Consecutive Days Analyses}

Spring and fall low-flow frequency statistics are calculated using the annual minimum mean discharges for any specific number of consecutive days ( $\mathrm{N}$-day) low flows on a seasonal basis by limiting the daily mean discharge data used for the annual series to just the season of interest. The mean discharge for each $\mathrm{N}$-day period throughout the annual 
spring or fall season is calculated and the minimum value is used for that annual spring or fall season. For example, the M7D10Y0406 low-flow statistic is calculated from the annual spring season (April through June) series of minimum 7-day mean flows for a streamgage. From the spring season daily mean discharge record, the mean flow for each consecutive 7-day period is determined and the lowest mean value for each year is assigned to that year in the annual spring season series. The spring season series of annual minimum 7-day values are then fit to a log-Pearson Type III distribution to determine the low-flow frequency (Riggs, 1972). More specific information about the log-Pearson Type III distribution is documented in Interagency Advisory Committee on Water Data (1982).

Annual spring and fall seasonal N-day discharge values for some streamgages included in this study were equal to zero. A conditional probability adjustment for zero flow values (Interagency Advisory Committee on Water Data, 1982, appendix 5) was used for low-flow frequency analyses for streamgages with one or more annual spring or fall seasonal $\mathrm{N}$-day discharge values of zero. The $\mathrm{N}$-day periods analyzed in this study for each annual spring and fall season were 1-, 7-, and 30-day periods.

\section{Trend Analyses}

The N-day data calculated for annual spring and fall seasons were analyzed for the period of record (table 1-1) for trends using the Kendall's tau hypothesis test. The Kendall's tau hypothesis test was computed within the "Trend" preprocessing step of the "Integrated Frequency Analysis" procedure within the USGS Surface-Water Toolbox computer program. Trends in the N-day data could introduce a bias into the lowflow frequency analyses because a primary assumption of frequency analyses is that annual spring and fall low flows are independent and stationary during a period of time. The Kendall's tau test computes the monotonic relation between $\mathrm{N}$-day values (discharge) and time (annual seasons) (Helsel and Hirsch, 2002). A p-value threshold of 5 percent $(\alpha=0.05)$ was used in this study for the Kendall's tau test and p-values less than or equal to 5 percent were flagged as having statistically significant trends (positive or negative).

The Kendall's tau test was performed for the six N-day time series at each streamgage - the annual spring minimum 1-, 7-, and 30-day low flows and the annual fall minimum 1-, 7-, and 30-day low flows. Results of the Kendall's tau tests indicated statistically significant positive trends for 137 streamgages, and statistically significant negative trends for 1 streamgage, of the 241 streamgages tested using the period of record (table 1-1); however, regulated streamgages on the Iowa, Chariton, Des Moines, Middle Raccoon, and Missouri Rivers (fig. 1) were tested for trends using the regulated period of record. Streamgages on the Mississippi River (fig. 1) were not considered regulated for this study for the trend analyses because the Mississippi River locks and dams were built for river navigation and have only a minimal regulatory effect on streamflows (Fischer and others, 1990). Streamgages on the Mississippi River were not included in the development of RREs because their drainage basins extend outside of the 50-mi buffer used for the study area.

Annual and seasonal precipitation data for Iowa were tested for trends using Kendall's tau analyses (Eash and Barnes, 2012). Although statistically significant trends in precipitation are apparent for some areas of Iowa for some of the periods of record tested, the precipitation data do not fully explain the low-flow trends. Changes in agricultural practices are hypothesized to be the primary cause of the positive lowflow trends in the State (Schilling and Libra, 2003; Schilling, 2005). A variable length of record for each streamgage (the longest, most recent period of record without a significant trend) was used in this study to try to minimize the bias of significant positive trends in the computation of selected spring and fall low-flow frequency statistics. A description of the variable record-length approach is presented Eash and Barnes (2012).

About 3,400 Kendall's tau trend analyses were computed as part of the variable-length record approach for this study. The longest period of record without a significant trend for all six N-day records for each streamgage is listed in table 1-1 under the column headings of "Period of record used for computing spring low-flow statistics" and "Period of record used for computing fall low-flow statistics." A difference in the period of record listed in these columns from the preceding column heading of "Period of record," indicates that a significant trend was determined for the period of record and a shorter period of record was used for the computation of selected spring and fall low-flow frequency statistics. If a significant trend was determined for the period of record for a streamgage, the same number of years of record was used for calculating the spring and fall low-flow frequency statistics dependent on the longest, most recent period of record without a significant trend for each season.

The number of years of record for the 211 streamgages included in the development of the spring RREs ranged from 10 to 80 years with a mean of 36 years and a median of 36 years. The number of years of record for the 208 streamgages included in the development of the fall RREs ranged from 10 to 79 years with a mean of 36 years and a median of 37 years. 


\section{Basin Characteristics}

Low-flow characteristics of streams are related to the physical, geologic, and climatic properties of drainage basins (Smakhtin, 2001). In most studies, drainage area is a significant variable in explaining low-flow variability (Funkhouser and others, 2008; Kroll and others, 2004). Basin characteristics investigated in this study as potential explanatory variables in the regression analysis were selected on the basis of their theoretical relation to low flows, results of previous studies in similar hydrologic areas, and the ability to quantify the basin characteristics using GIS technology and digital data-sets. The use of GIS enables the automation of the basin-characteristic measurements and solution of the RREs using StreamStats.

Using GIS technology, 63 basin characteristics were measured for each of the 211 streamgages included in this study for the development of RREs. A brief description of each basin characteristic and the data source used to measure the characteristic are listed in table 1. Basin-characteristic names used in this study were selected to maintain consistency with the names of explanatory variables in the USGS StreamStats Web-based GIS application (http://streamstatsags.cr.usgs.gov/ ss_defs/basin_char_defs.aspx).

Similar GIS-measurement methods were used in this study as were used in the previous low-flow study for Iowa (Eash and Barnes, 2012), with the exception that Arc Hydro Tools (x64), version 10.3.0.39 with ArcGIS 10.3.1 for Desktop, version 10.3.4959 (Environmental Systems Research Institute, Inc., 2014) and a batch-processing method to measure basin characteristics for multiple streamgage sites were used for this study. The batch-processing method (http:// streamstatsags.cr.usgs.gov/ss_bp/) was performed locally using GIS data layers created for Iowa StreamStats. The landuse characteristics were computed from National Land Cover Database (NLCD) 2011 datasets (Homer and others, 2015) and the climatic characteristics were computed from Oregon State University Parameter-elevation Regressions on Independent Slopes Model (PRISM) datasets (PRISM Climate Group, 2016). For this study, 24 new GIS data layers for a 50-mi buffer of Iowa were created for the measurement of 15 new basin characteristics (table 1; Homer and others, 2015; Wolock and others, 2004; PRISM Climate Group, 2016) that were not included in the previous low-flow study for Iowa. The 15 new basin characteristics are listed in table 1 with green text; the characteristics were selected on the basis of recent low-flow studies for Minnesota (Ziegeweid and others, 2015) and Missouri (Southard, 2013).

Because the final Watershed Boundary Dataset (WBD) certified for Iowa by the U.S. Department of Agriculture, Natural Resources Conservation Service (2016) became available for Iowa following the measurement of basin characteristics for the previous low-flow study for Iowa (Eash and Barnes, 2012), all 63 basin characteristics listed in table 1 were either newly measured (15 basin characteristics) or remeasured (48 basin characteristics) for this study. Fifteen of 48 basin characteristics that were measured in the previous low-flow study for Iowa were remeasured for this study using updated PRISM Climate Group (2016) data layers or a newly created NLCD data layer (Homer and others, 2015; LC11ACROP) (table 1). The 15 basin characteristics that were remeasured with updated GIS data layers are listed in table 1 with red text. A 10-meter digital elevation model (DEM) was used locally for the measurement of basin characteristics for this study. The DEM is hydrologically enforced using previously processed National Hydrography Dataset (NHD) data (Eash and Barnes, 2012) and the newer certified WBD data; this DEM has been used nationally for the measurement of basin characteristics since Iowa StreamStats was first implemented in June 2013. Thus, a comparison of basin-characteristic values for all 48 remeasured basin characteristics listed for streamgages in table 1-1 in this report may be different from those published in the previous low-flow study report (Eash and Barnes, 2012).

Hydrologic basin characteristics (base-flow index [BFI], hydrograph separation and analysis [HYSEP], annual baseflow-recession time constant [TAU_ANN], seasonal baseflow-recession time constant computed for October through December [TAU10_12], and streamflow-variability index [STREAM_VAR]) that were tested for significance for the development of regression equations in the previous low-flow study for Iowa (Eash and Barnes, 2012) were not tested for significance for the development of regression equations in this study as a result of verbal discussions with members of the USGS Office of Surface Water. This decision was based on the fact that hydrologic-characteristic values cannot be calculated directly for ungaged sites and have to be estimated; therefore, the inclusion of hydrologic characteristics as variables in the development of regression equations adds a level of uncertainty that is not directly reflected in the performance metrics provided for the regression equations.

In addition to the five hydrologic basin characteristics, a sixth basin characteristic (the percent area with slopes greater than 30 percent facing north [NFSL30]) that was tested for significance for the development of regression equations in the previous low-flow study for Iowa (Eash and Barnes, 2012) was not tested for significance for the development of regression equations in this study because a theoretical relation to low flows was not indicated in the previous study. Therefore, the 63 basin characteristics measured in this study for the development of RREs are accounted for with the exclusion of 6 basin characteristics from the 54 basin characteristics measured in the previous low-flow study and with the addition of 15 new basin characteristics measured in this study (listed in table 1 with green text). Of the remaining 48 basin characteristics measured in this study, 15 of the characteristics were remeasured using updated GIS data layers (listed in table 1 with red text). 
Table 1. Basin characteristics tested for significance in developing regression equations.

[DEM, digital elevation model; m, meters; WBD, Watershed Boundary Dataset; 24K, 1:24,000-scale; $\pi$, pi a mathematical constant commonly approximated as 3.14; NHD, National Hydrography Dataset; NLCD, National Land Cover Database. Basin characteristics included in this study that were not included in the previous low-flow study (Eash and Barnes, 2012) are listed in green. Basin characteristics measured in the previous low-flow study (Eash and Barnes, 2012) that were remeasured for this study using updated data layers are listed in red]

\begin{tabular}{|c|c|}
\hline Characteristics & Source data \\
\hline \multicolumn{2}{|c|}{ Morphometric } \\
\hline $\begin{array}{l}\text { DRNAREA — Geographic information system (GIS) drainage area } \\
\quad \text { (square miles) }\end{array}$ & $\begin{array}{l}\text { DEM (10 m) http://nationalmap.gov/elevation.html; WBD (24K) } \\
\text { https://gdg.sc.egov.usda.gov/ }\end{array}$ \\
\hline BASINPERIM—Basin perimeter (miles) & $\begin{array}{l}\text { DEM (10 m) http://nationalmap.gov/elevation.html; WBD (24K) } \\
\text { https://gdg.sc.egov.usda.gov/ }\end{array}$ \\
\hline $\begin{array}{l}\text { BASLENAH_-Basin length (miles), measured along a line are- } \\
\text { ally centered through the basin polygon from end points of } \\
\text { LFPLENGTH }\end{array}$ & $\begin{array}{l}\text { DEM (150 m) http://nationalmap.gov/elevation.html; WBD (24K) } \\
\text { https://gdg.sc.egov.usda.gov/ }\end{array}$ \\
\hline $\begin{array}{l}\text { BSLDEM10M-Average basin slope computed from 10-m DEM } \\
\text { (percent) }\end{array}$ & DEM (10 m) http://nationalmap.gov/elevation.html \\
\hline
\end{tabular}

RELIEF-Basin relief computed as maximum elevation minus minimum elevation (feet)

RELRELF-Relative relief computed as RELIEF divided by BASINPERIM (feet per mile)

BSHAPE - Shape factor measure of basin shape computed as BASLENAH squared divided by DRNAREA (dimensionless)

ELONGRATIO - Elongation ratio measure of basin shape, ratio of (1) the diameter of a circle of area equal to that of the basin to (2) the length of the basin, ELONGRATIO $=[4$ DRNAREA $/ \pi$ $\left.(\mathrm{BASLENAH})^{2}\right]^{0.5}$ (dimensionless)

ROTUND - Rotundity of basin measure of basin shape, ROTUND = $\left[\pi(\text { BASLENAH) })^{2}\right] /[4$ DRNAREA] (dimensionless)

COMPRAT - Compactness ratio measure of basin shape, is the ratio of the perimeter of the basin to the circumference of a circle of equal area, COMPRAT $=$ BASINPERIM/2 $(\pi \text { DRNAREA })^{0.5}$ (dimensionless)

LFPLENGTH - Length of longest flow path as measured from basin outlet to basin divide (miles)

MCSRBSFT - Main-channel sinuosity ratio computed as LFPLENGTH divided by BASLENAH (dimensionless)

STRMTOTED - Total length of mapped streams in basin, from edited 24K NHD (miles)

STRDEN-Stream density computed as STRMTOTED divided by DRNAREA (miles per square mile)

SLENRAT - Slenderness ratio computed as LFPLENGTH squared divided by DRNAREA (dimensionless)

CCM - Constant of channel maintenance computed as DRNAREA divided by STRMTOTED (square miles per mile)

CSL1085LFP_Stream slope computed as the change in elevation between points 10 and 85 percent of length of LFPLENGTH divided by length between the points (feet per mile)

CSL100-Stream slope computed as entire LFPLENGTH (feet per mile)

MCSP-Main-channel slope proportion computed as LFPLENGTH divided by the square root of CSL1085LFP (dimensionless)

RUGGED - Ruggedness number computed as STRDEN multiplied by RELIEF (feet per mile)

DEM (10 m) http://nationalmap.gov/elevation.html

DEM (10 m) http://nationalmap.gov/elevation.html; WBD (24K) https://gdg.sc.egov.usda.gov/

DEM (10 m) http://nationalmap.gov/elevation.html; WBD (24K) https://gdg.sc.egov.usda.gov/

DEM (10 m) http://nationalmap.gov/elevation.html; WBD (24K) https://gdg.sc.egov.usda.gov/

DEM (10 m) http://nationalmap.gov/elevation.html; WBD (24K) https://gdg.sc.egov.usda.gov/

DEM (10 m) http://nationalmap.gov/elevation.html; WBD (24K) https://gdg.sc.egov.usda.gov/

DEM (10 m) http://nationalmap.gov/elevation.html; NHD (24K) http://nhd.usgs.gov/

DEM (10 m) http://nationalmap.gov/elevation.html; WBD (24K) https://gdg.sc.egov.usda.gov/; NHD (24K) http://nhd.usgs.gov/

DEM (10 m) http://nationalmap.gov/elevation.html; NHD (24K) http://nhd.usgs.gov/

DEM (10 m) http://nationalmap.gov/elevation.html; WBD (24K) https://gdg.sc.egov.usda.gov/; NHD (24K) http://nhd.usgs.gov/

DEM (10 m) http://nationalmap.gov/elevation.html; WBD (24K) https://gdg.sc.egov.usda.gov/; NHD (24K) http://nhd.usgs.gov/

DEM (10 m) http://nationalmap.gov/elevation.html; WBD (24K) https://gdg.sc.egov.usda.gov/; NHD (24K) http://nhd.usgs.gov/

DEM (10 m) http://nationalmap.gov/elevation.html; NHD (24K) http://nhd.usgs.gov/

DEM (10 m) http://nationalmap.gov/elevation.html; NHD (24K) http://nhd.usgs.gov/

DEM (10 m) http://nationalmap.gov/elevation.html; NHD (24K) http://nhd.usgs.gov/

DEM (10 m) http://nationalmap.gov/elevation.html; WBD (24K) https://gdg.sc.egov.usda.gov/; NHD (24K) http://nhd.usgs.gov/ 
Table 1. Basin characteristics tested for significance in developing regression equations.-Continued

[DEM, digital elevation model; m, meters; WBD, Watershed Boundary Dataset; 24K, 1:24,000-scale; $\pi$, pi a mathematical constant commonly approximated as 3.14; NHD, National Hydrography Dataset; NLCD, National Land Cover Database. Basin characteristics included in this study that were not included in the previous low-flow study (Eash and Barnes, 2012) are listed in green. Basin characteristics measured in the previous low-flow study (Eash and Barnes, 2012) that were remeasured for this study using updated data layers are listed in red]

\begin{tabular}{l} 
Characteristics \\
\hline Morphometric- \\
\hline SLOPERAT_-Slope ratio computed as CSL1085LFP divided by \\
BSLDEM10M (dimensionless) \\
FOSTREAM_-Number of first-order streams within basin using the \\
Strahler stream ordering method (dimensionless) \\
DRNFREQ_-Drainage frequency computed as FOSTREAM divided \\
by DRNAREA (number of first-order streams per square mile) \\
RSD_Relative stream density computed as FOSTREAM multiplied \\
by DRNAREA and divided by STRMTOTED squared (dimension- \\
less) \\
SLOP30_10M-Percent area with slopes greater than 30 percent \\
PFLATTOT_-Total percent flat land (slope less than 1 percent) in \\
watershed (percent) \\
PFLATLOW_-Percent flat land (slope less than 1 percent) in water- \\
shed lowland (elevation less than midpoint between minimum and \\
maximum elevation) (percent) \\
PFLATUP_-Percent flat land (slope less than 1 percent) in watershed \\
upland (elevation greater than or equal to midpoint between mini- \\
mum and maximum elevation) (percent)
\end{tabular}

Source data

Continued

DEM (10 m) http://nationalmap.gov/elevation.html; NHD (24K) http://nhd.usgs.gov/

DEM (10 m) http://nationalmap.gov/elevation.html; NHD (24K) http://nhd.usgs.gov/

DEM (10 m) http://nationalmap.gov/elevation.html; WBD (24K) https://gdg.sc.egov.usda.gov/; NHD (24K) http://nhd.usgs.gov/

DEM (10 m) http://nationalmap.gov/elevation.html; WBD (24K) https://gdg.sc.egov.usda.gov/; NHD (24K) http://nhd.usgs.gov/

DEM (10 m) http://nationalmap.gov/elevation.html

Wolock and others (2004); http://water.usgs.gov/GIS/metadata/ usgswrd/XML/hlrus.xml

Wolock and others (2004); http://water.usgs.gov/GIS/metadata/ usgswrd/XML/hlrus.xml

Wolock and others (2004); http://water.usgs.gov/GIS/metadata/ usgswrd/XML/hlrus.xml

\footnotetext{
SSURGOA - Percent area underlain by hydrologic soil type A (percent area)

SSURGOB - Percent area underlain by hydrologic soil type B (percent area)

SSURGOC - Percent area underlain by hydrologic soil type C (percent area)

SSURGOD - Percent area underlain by hydrologic soil type D (percent area)

SSURGSAND_-Percent volume of sand content of soil (percent volume)

SSURGOCLAY - Percent volume of clay content of soil (percent volume)

SSURGOKSAT - Average soil permeability or saturated hydraulic conductivity of soil (micrometers per second)

DESMOIN-Percent area of basin within Des Moines Lobe landform region (percent area)

LC11ACROP_Percent area of cultivated crops from NLCD 2011 class 82 (percent area)

LC11ADECID_-Percent area of deciduous forest from NLCD 2011 class 41 (percent area)

LC11APAST - Percent area of pasture/hay from NLCD 2011 class 81 (percent area)

LC11CRPHAY - Percent area of cultivated crops and hay from NLCD 2011 classes 81 and 82 (percent area)

LC11AWETL - Percent area of wetlands from NLCD 2011 classes 90 and 95 (percent area)
}

Pedologic/geologic/land-use

http://websoilsurvey.sc.egov.usda.gov/

http://websoilsurvey.sc.egov.usda.gov/

http://websoilsurvey.sc.egov.usda.gov/

http://websoilsurvey.sc.egov.usda.gov/

http://websoilsurvey.sc.egov.usda.gov/

http://websoilsurvey.sc.egov.usda.gov/

http://websoilsurvey.sc.egov.usda.gov/

https://programs.iowadnr.gov/nrgislibx/

Homer and others (2015); http://www.mrlc.gov/nlcd2011.php

Homer and others (2015); http://www.mrlc.gov/nlcd2011.php

Homer and others (2015); http://www.mrlc.gov/nlcd2011.php

Homer and others (2015); http://www.mrlc.gov/nlcd2011.php

Homer and others (2015); http://www.mrlc.gov/nlcd2011.php 
Table 1. Basin characteristics tested for significance in developing regression equations.-Continued

[DEM, digital elevation model; m, meters; WBD, Watershed Boundary Dataset; 24K, 1:24,000-scale; $\pi$, pi a mathematical constant commonly approximated as 3.14; NHD, National Hydrography Dataset; NLCD, National Land Cover Database. Basin characteristics included in this study that were not included in the previous low-flow study (Eash and Barnes, 2012) are listed in green. Basin characteristics measured in the previous low-flow study (Eash and Barnes, 2012) that were remeasured for this study using updated data layers are listed in red]

\begin{tabular}{|c|c|}
\hline Characteristics & Source data \\
\hline \multicolumn{2}{|c|}{ Pedologic/geologic/land-use-Continued } \\
\hline $\begin{array}{l}\text { LC11IMP_-Percent area of impervious area from NLCD } 2011 \mathrm{im}- \\
\text { pervious data set (percent area) }\end{array}$ & Homer and others (2015); http://www.mrlc.gov/nlcd2011.php \\
\hline $\begin{array}{l}\text { LC11DEV_-Percent area of developed area from NLCD } 2011 \\
\text { classes 21-24 (percent area) }\end{array}$ & Homer and others (2015); http://www.mrlc.gov/nlcd2011.php \\
\hline
\end{tabular}

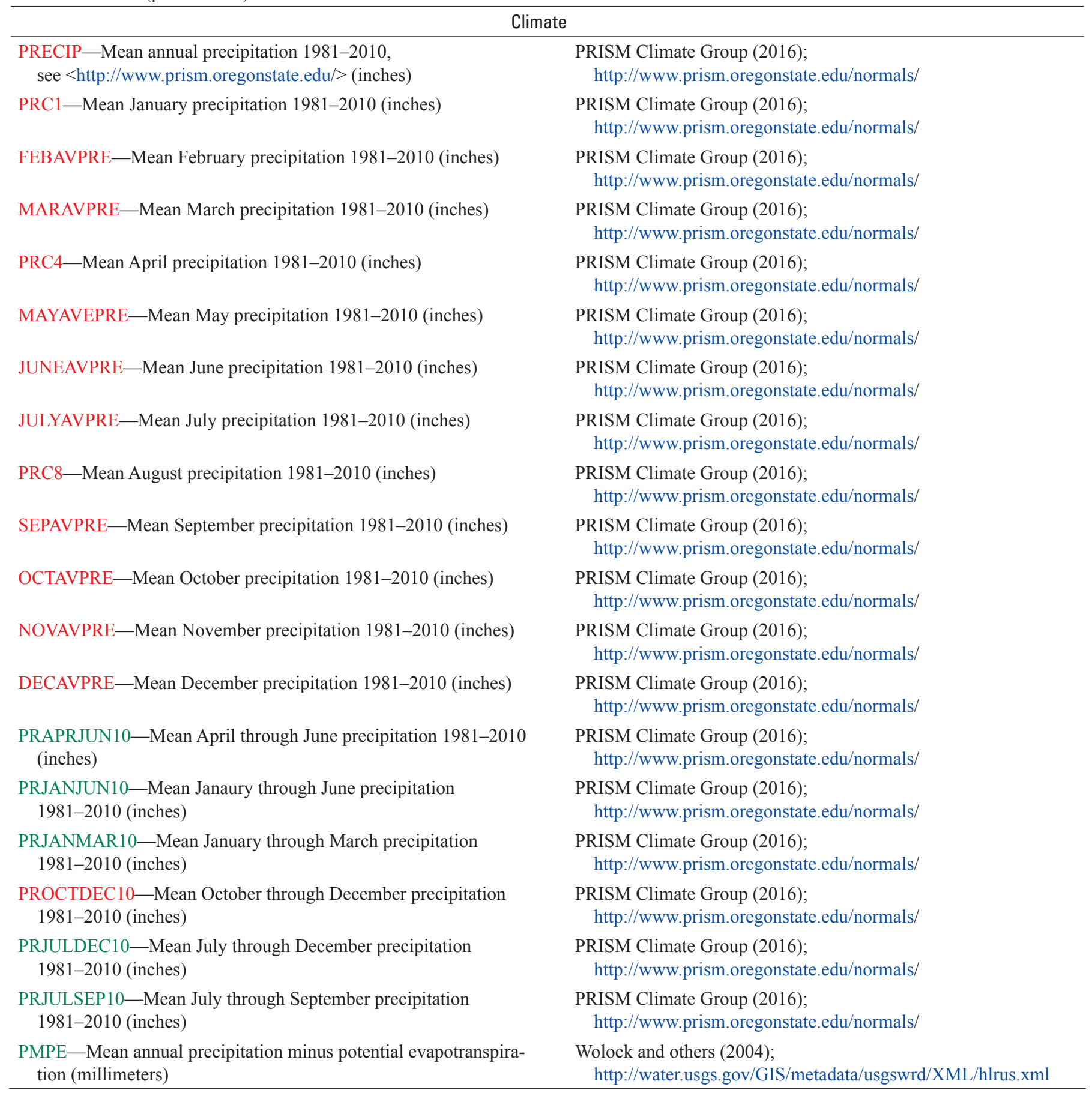




\section{Estimating Selected Spring and Fall Low-Flow Frequency Statistics for Ungaged Stream Sites}

In a regional regression study, subdividing a large study area into subregions that are relatively homogeneous in terms of low-flow hydrology typically helps to reduce error in the regression equations. The same three low-flow regions (northeast, northwest, and southern) defined for Iowa from regionalization performed in the previous low-flow study (Eash and Barnes, 2012) were used for the development of RREs in this study (fig. 1). Streamgages in Minnesota and Missouri were selected for inclusion in the development of regression equations for this study on the basis of their selection for use in the development of low-flow regression equations for those states (Ziegeweid and others, 2015; Southard, 2013). The 16 streamgages removed from the regression analyses for this study and the reasons for their removal are listed in table 2 . These 16 streamgages were either included in the development of regression equations for the previous study (Eash and Barnes, 2012) or since the previous study, have at least 10 years of streamflow record available for this study. Streamgage 05476000 Des Moines River at Jackson, Minn. (map number 114), which was not included in the development of regression equations in the previous study (Eash and Barnes, 2012), was included in the development of regression equations for this study because this streamgage was included in the development of Minnesota low-flow regression equations (Ziegeweid and others, 2015). Data collected for 211 streamgages were compiled into regional datasets for the development of RREs for this study.

\section{Development of Regional Regression Equations}

Differences in the percentage of streamgages with estimates of zero flow, computed from observed streamflow for the selected spring and fall low-flow frequency statistics, required the use of different regression analyses. The percentage of streamgages with estimates of zero flow computed from observed streamflow for each selected statistic for each region are listed in the shaded columns in table 3. Estimates of zero flow computed from observed streamflow are commonly considered to be censored data (Kroll and Stedinger, 1996; Kroll and Vogel, 2002), and the use of multiple-linear regression is not recommended for censored data (Helsel and Hirsch, 2002). The choice of censored-regression methods depends on the amount of censoring in each region for each low-flow frequency statistic (Helsel and Hirsch, 2002; Eash and Barnes, 2012).

Table 2. Streamgages removed from the regression analyses.

[USGS, U.S. Geological Survey; Minn., Minnesota; Mo., Missouri]

\begin{tabular}{|c|c|c|}
\hline $\begin{array}{c}\text { USGS } \\
\text { streamgage } \\
\text { number }\end{array}$ & Streamgage name & Reason for removal of streamgage from regression analyses \\
\hline 05385500 & South Fork Root River near Houston, Minn. & Less than 10 years of record after removing substantial trend. ${ }^{1}$ \\
\hline 05417000 & Maquoketa River near Manchester, Iowa & Used active streamgage 05416900 . \\
\hline 05418450 & North Fork Maquoketa River at Fulton, Iowa & Used active streamgage 05418400. \\
\hline 05457000 & Cedar River near Austin, Minn. & Upstream discharges from wastewater treatment plant affect low flows. ${ }^{1}$ \\
\hline 05500000 & South Fabius River near Taylor, Mo. & Inconsistent data at the lower end of the rating curve. ${ }^{2}$ \\
\hline 05503000 & Oak Dale Branch near Emden, Mo. & Inconsistent data at the lower end of the rating curve. ${ }^{2}$ \\
\hline 06600000 & Perry Creek at 38th Street, Sioux City, Iowa & Urbanization. \\
\hline 06813000 & Tarkio River at Fairfax, Mo. & Inconsistent data at the lower end of the rating curve. ${ }^{2}$ \\
\hline 06898100 & Thompson River at Mount Moriah, Mo. & Inconsistent data at the lower end of the rating curve. ${ }^{2}$ \\
\hline 06898500 & Weldon River near Mercer, Mo. & Inconsistent data at the lower end of the rating curve. ${ }^{2}$ \\
\hline 06899000 & Weldon River at Mill Grove, Mo. & Inconsistent data at the lower end of the rating curve. ${ }^{2}$ \\
\hline 06902500 & Hamilton Branch near New Boston, Mo. & Inconsistent data at the lower end of the rating curve. ${ }^{2}$ \\
\hline
\end{tabular}

${ }^{1}$ Jeffrey Ziegeweid, U.S. Geological Survey, written commun., 2016.

${ }^{2}$ Rodney Southard, U.S. Geological Survey, written commun., 2016. 
Table 3. Percentage of streamgages with estimates of zero flow computed from observed streamflow for selected spring and fall lowflow frequency statistics in each region of lowa.

$[\mathrm{N}$, number of streamgages; *, differences in the number of streamgages between spring- and fall-frequency analyses is because some fall records only have 9 years of record, and these streamgages were not included in the development of fall-frequency equations; Q, low-flow estimate computed from observed streamflow (cubic feet per second); >, greater than; M1D10Y0406, spring (April through June) 1-day mean low flow with a recurrence interval of 10 years; M7D10Y0406, spring (April through June) 7-day mean low flow with a recurrence interval of 10 years; M30D10Y46, spring (April through June) 30-day mean low flow with a recurrence interval of 10 years; M1D10Y1012, fall (October through December) 1-day mean low flow with a recurrence interval of 10 years; M7D10Y1012, fall (October through December) 7-day mean low flow with a recurrence interval of 10 years; M30D10YOD, fall (October through December) 30-day mean low flow with a recurrence interval of 10 years; shaded column, the percentage of streamgages with estimates of zero flow computed from observed streamflow for each selected statistic for the region]

\begin{tabular}{|c|c|c|c|c|c|c|c|c|c|}
\hline \multirow[t]{2}{*}{ Statistic } & \multicolumn{3}{|c|}{$\begin{array}{c}\text { Northeast region } \\
\text { ( } \mathrm{N}=62 \text { for spring-frequency analyses; } \\
\mathrm{N}=61 \text { for fall-frequency analyses*) }\end{array}$} & \multicolumn{3}{|c|}{$\begin{array}{c}\text { Northwest region } \\
\text { ( } \mathrm{N}=45 \text { for spring-frequency analyses; } \\
\mathrm{N}=44 \text { for fall-frequency analyses*) }\end{array}$} & \multicolumn{3}{|c|}{$\begin{array}{c}\text { Southern region } \\
\text { ( } \mathrm{N}=104 \text { for spring-frequency analyses; } \\
\mathrm{N}=103 \text { for fall-frequency analyses*) }\end{array}$} \\
\hline & $\mathbf{N}$ with $\mathbf{0}>0$ & $\mathrm{~N}$ with $\mathrm{Q}=\mathbf{0}$ & $\begin{array}{c}0=0 \\
\text { (percent) }\end{array}$ & $\mathrm{N}$ with $\mathrm{Q}>0$ & $\mathrm{~N}$ with $\mathrm{Q}=\mathbf{0}$ & $\begin{array}{c}0=0 \\
\text { (percent) }\end{array}$ & $\mathrm{N}$ with $\mathrm{Q}>0$ & $\mathrm{~N}$ with $\mathrm{Q}=\mathbf{0}$ & $\begin{array}{c}\mathbf{0}=\mathbf{0} \\
\text { (percent) }\end{array}$ \\
\hline M1D10Y0406 & 62 & 0 & 0 & 41 & 4 & 9 & 97 & 7 & 7 \\
\hline M7D10Y0406 & 62 & 0 & 0 & 41 & 4 & 9 & 99 & 5 & 5 \\
\hline M1D10Y1012 & 60 & 1 & 2 & 36 & 8 & 18 & 84 & 19 & 18 \\
\hline M7D10Y1012 & 60 & 1 & 2 & 36 & 8 & 18 & 87 & 16 & 16 \\
\hline M30D10YOD & 61 & 0 & 0 & 38 & 6 & 14 & 99 & 4 & 4 \\
\hline
\end{tabular}

A substantial number of streamgages included in the development of RREs have estimates of zero flow calculated from observed streamflow for selected spring and fall lowflow frequency statistics; therefore, two types of regression analyses were performed to develop the final equations for the three low-flow regions-left-censored and generalized-leastsquares (GLS) regression analyses. Left-censored regression analyses (Lorenz, 2014) were performed to allow the use of a censoring threshold $\left(0.1\right.$ cubic foot per second $\left.\left[\mathrm{ft}^{3} / \mathrm{s}\right]\right)$ in the development of equations to estimate the three spring low-flow frequency statistics (M1D10Y0406, M7D10Y0406, and M30D10Y46) for the southern and northwest regions and in the development of equations to estimate the three fall low-flow frequency statistics (M1D10Y1012, M7D10Y1012, and M30D10YOD) for all three low-flow regions. The leftcensored regression analyses were weighted on the basis of streamgage record length. For the northeast region, GLS multiple-linear regression analyses (Eng and others, 2009) were used in the development of equations to estimate the three spring low-flow frequency statistics (M1D10Y0406, M7D10Y0406, and M30D10Y46) because streamgages in this region did not have any estimates of zero flow calculated from observed streamflow. The GLS multiple-linear regression analyses were weighted on the basis of streamgage record length and on the variance and cross correlation of the spring low flows. Cross correlation accounts for the correlation of concurrent streamflow in the time series of each pair of streamgages in a region (Eng and others, 2009), and less weight is factored for streamgages that have greater cross correlation as part of the overall weighting used in GLS regression.
If observed low-flow frequency statistics did not estimate any zero flows, which is the case for the three spring lowflow frequency statistics for the northeast region, then a GLS multiple-linear regression was used. If less than 20 percent of the observed low-flow frequency statistics were zero flow, then a left-censored regression method was used because a censoring threshold only applies to the lower-end of the lowflow frequency statistics. If between 20 and 50 percent of the observed low-flow frequency statistics were zero flow, then a logistic regression method would be used to first estimate the probability of zero flow at ungaged sites and then, if necessary, a multiple linear regression would be used to estimate lowflow frequency statistics for sites that are likely to have flow, based on the logistic-regression equations estimate (Eash and Barnes, 2012). Because the percentage of streamgages with estimates of zero flow are less than 20 percent, a left-censoredregression method was used in the development of all RREs to estimate spring and fall low-flow frequency statistics for this study, with the exception of the spring low-flow frequency statistics for the northeast region.

Although estimates of zero flow are not calculated from observed streamflow for any streamgages in the northeast region for one of the three fall low-flow frequency statistics (M30D10YOD; table 3) or for any streamgages in the southern region for one of the three spring low-flow frequency statistics (M30D10Y46; table 3), and although multiple-linear regression is applicable, left-censored regression was used to develop all three fall and all three spring low-flow frequency equations for the northeast and southern regions, respectively. For the northeast region, the same regression method was 
used to develop all three fall low-flow frequency equations to avoid the possibility of inconsistencies in estimates, such as an estimate of M7D10Y1012 exceeding an estimate of M30D10YOD. Likewise, for the southern region, the same regression method was used to develop all three spring lowflow frequency equations to avoid the possibility of inconsistencies in estimates, such as an estimate of M7D10Y0406 exceeding an estimate of M30D10Y46. Final left-censored regression models were selected primarily on the basis of minimizing values of the average standard error of estimate (SEE) (Helsel and Hirsch, 2002).

A description of multiple-linear regression, including GLS regression, and a description of left-censored regression is presented in Eash and Barnes (2012). Compared to weighted-least-squares (WLS) regression, GLS regression may not be as appropriate for the development of equations for the estimation of low-flow frequency statistics if a set of basin characteristics cannot be identified that describes most of the variability of the low-flow frequency statistics (Ken Eng, U.S. Geological Survey, written commun., 2007). The GLS regression is considered more appropriate than WLS regression if low-flow regression data are highly correlated spatially (Ken Eng, U.S. Geological Survey, written commun., 2009), which is the case for the spring low-flow data for the northeast region. The correlation smoothing function used by the weighted-multiple-linear regression (WREG) program (Eng and others, 2009; Wagner and others, 2016) to compute a weighting matrix for the 62 streamgages included in the development of the GLS regression equation for estimating M7D10Y0406 for the northeast region with 30 years of concurrent flow is shown in figure 2. The smoothing function relates the correlation between annual spring low-flow time series at two streamgages to the geographic distance between the streamgages for every paired combination of the 62 streamgages with 30 years of concurrent flow data (annual series of spring minimum 7-day mean low flows for all streamgages in the northeast region is shown in figure 2). Strong evidence of cross correlation is shown in figure 2, justifying the use of GLS regression rather than WLS regression, because of the abundance of paired points for 30 years of concurrent flow that extend downwards to the right in the figure.

In addition, GLS regression is justified rather than WLS regression because pseudo coefficient of determination (pseudo- $\mathrm{R}^{2}$ ) values for all three spring low-flow equations developed for the northeast region exceed 90 percent (table 4; Ken Eng, U.S. Geological Survey, written commun., 2007). The pseudo- $\mathrm{R}^{2}$ is a measure of the percentage of the variation explained by the basin characteristics (explanatory variables) included in the model. The pseudo- $\mathrm{R}^{2}$ value is calculated on the basis of the degrees of freedom in the regression (Griffis and Stedinger, 2007). Final GLS regression models were selected primarily on the basis of minimizing values of the standard error of model (SEM) (Eng and others, 2009) and the average standard error of prediction (SEP) (Griffis and Stedinger, 2007; Eng and others, 2009) and maximizing values of the pseudo- ${ }^{2}$.

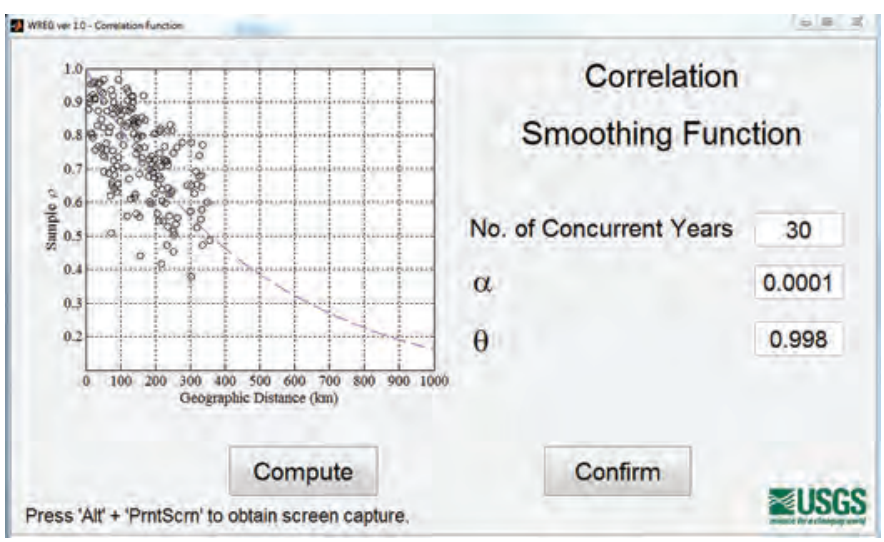

\section{EXPLANATION}

Rho $(\rho)$, dimensionless, is the estimated value for the cross-correlation of the time series of flow values used to calculate the streamflow characteristic at a given pair of streamgages

Alpha $(\alpha)$, dimensionless, is a parameter that affects how close to $0 \rho$ can get as the distance between a given pair of streamgages increases

Theta $(\theta)$, dimensionless, is a parameter that affects how quickly $\rho$ decreases as the distance between a given pair of streamgages increases

Figure 2. Screenshot of the weighted-multiple-linear regression program (WREG) smoothing function for generalized-least-squares (GLS) correlation of the time series of annual spring (April through June) minimum 7-day mean flows as a function of distance between 62 streamgages in the northeast region with 30 years of concurrent flow. 


\section{Final Regression Equations}

Final regression equations developed for the northeast, northwest, and southern regions defined for Iowa are listed in tables 4,5 , and 6, respectively. Also listed in tables 4-6 are the number of streamgages included in each regression analysis and several performance metrics. StreamStats variable names are used for the response and explanatory variables in the final regression equations (tables 4-6); definitions of the explanatory variables and the units of measure are listed in table 1. Eight basin characteristics are used as explanatory variables in the final regression equations (tables 4-6, table 1-1 of the appendix). These characteristics include three morphometric characteristics (GIS drainage area [DRNAREA], average basin slope computed from 10-meter DEM [BSLDEM10M], and drainage frequency [DRNFREQ]); four pedologic/landuse characteristics (hydrologic soil type A [SSURGOA], hydrologic soil type C [SSURGOC], hydrologic soil type D [SSURGOD], and percent of cultivated crops and hay from NLCD 2011 classes 81 and 82 [LC11CRPHAY]); and one climatic characteristic (mean July through December precipitation 1981-2010 [PRJULDEC10]). The GIS software is required to measure the basin characteristics included as explanatory variables in the final regression equations. All explanatory variables included in the final regression equations were statistically significant at the 95 -percent confidence level and were not correlated with other explanatory variables used in the same equation. The performance metrics in tables 4-6 indicate the predictive accuracy of the final regression equations. Because two types of regression were used to develop the final equations, performance metrics are reported differently for each type of regression. A description of the performance metrics reported for the left-censored and GLS regressions is presented in Eash and Barnes (2012).

\section{Accuracy and Limitations of Regression Equations}

The RREs developed in this study apply only to stream sites in Iowa where low flows are not substantially affected by regulation, diversion, or urbanization. The applicability and accuracy of the RREs depend on if the basin characteristics measured for an ungaged stream site are within the range of the characteristic values used to develop the regression equations. The acceptable range of basin-characteristic values used to develop each RRE (tables 4-6) is tabulated as minimum and maximum values in table 7 . The applicability of the RREs is unknown when any characteristic value measured for an ungaged site is outside the acceptable range. In addition, basin-characteristic measurements at ungaged sites should be computed using the same GIS datasets and measurement methods used in this study; the USGS StreamStats Web-based GIS application includes the same GIS data layers and measurement methods used in this study.

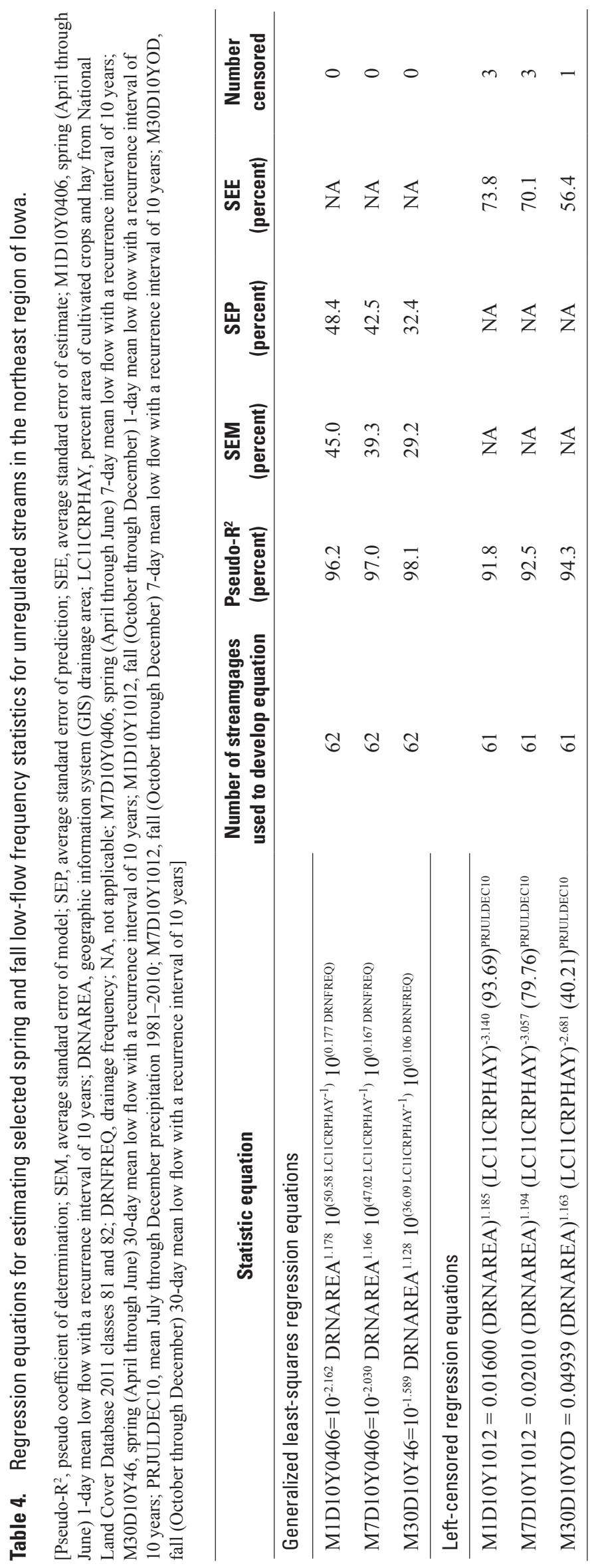



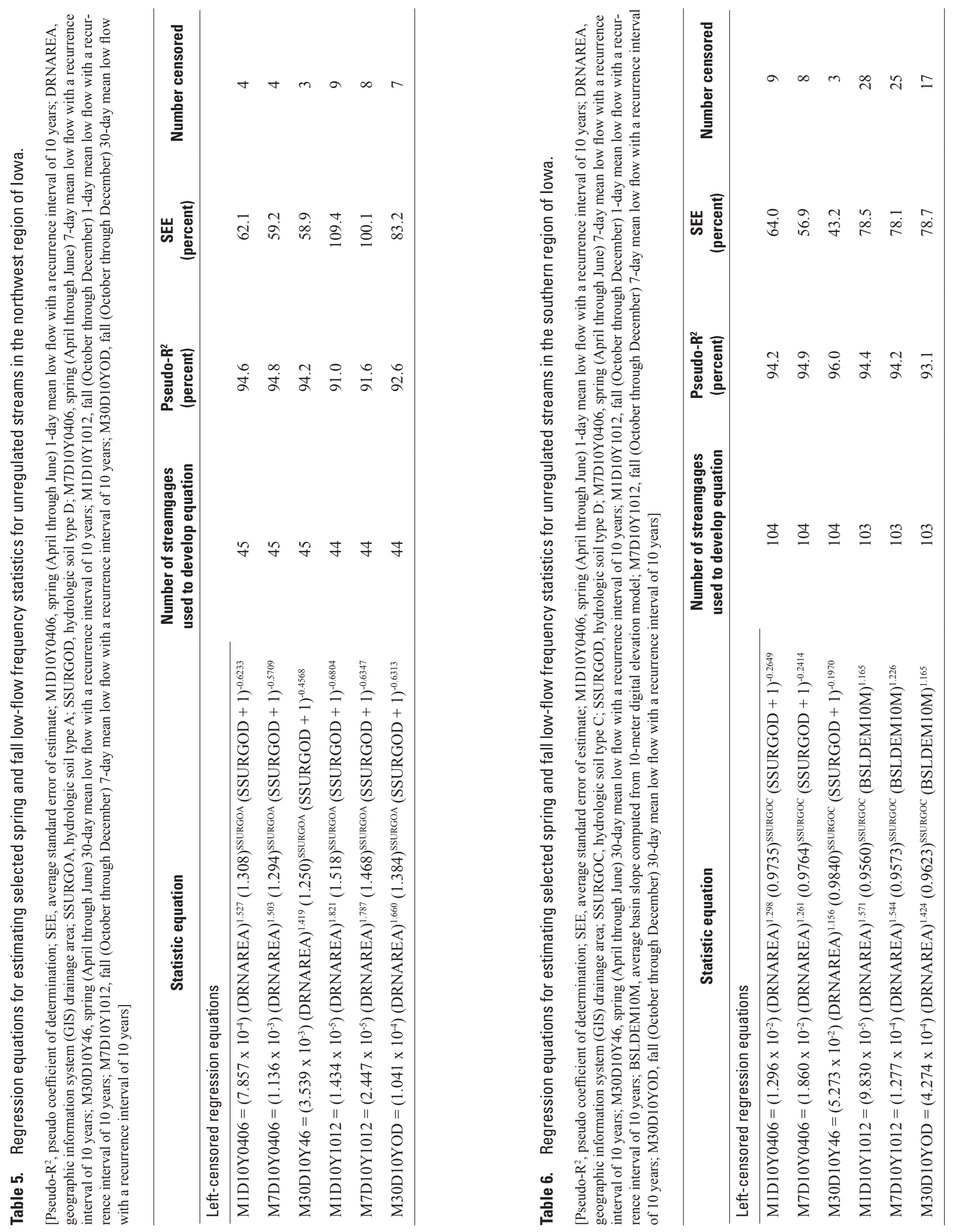
The low-flow frequency RREs presented in this report should be used with caution for ungaged stream sites with basin-characteristic values approaching the minimum or maximum limits (table 7) because inconsistencies in the estimates may result. Inconsistencies in estimates occur for ungaged sites when the discharge estimate for a smaller N-day is greater than the discharge estimate for a larger N-day. For example, a M7D10Y0406 discharge may be estimated to be greater than a M30D10Y46 discharge. Inconsistencies in estimates occurred for three of the streamgages listed in table 1-1, likely because some of their basin-characteristic values are near the minimum or maximum limits listed in table 7. For the northeast region, the predicted discharge for M7D10Y0406 exceeds the predicted discharge for M30D10Y46 for streamgages 05410000 and 05410490 (map numbers 27 and 28, respectively) and the predicted discharge for M7D10Y1012 exceeds the predicted discharge for M30D10YOD for streamgage 05408000 (map number 23).

Attempts were made to reduce the occurrence of inconsistencies in estimates by using the same explanatory variables for each regional set of spring and fall low-flow frequency equations. However, inconsistencies in estimates still may occur because RREs were developed separately and have variable prediction intervals depending on the size and variability of the datasets used to develop the regression equations. If inconsistencies in estimates are obtained for an ungaged stream site, a comparison of all low-flow frequency estimates for the site and a check of streamgage data or other published data may help to determine which low-flow frequency statistic is inconsistent. There is not an established solution for addressing the problem of inconsistencies in estimates obtained for an ungaged stream site.

Although reported SEE and SEP performance metrics are not directly comparable between the RREs, predictive accuracies generally tend to be the best for the northeast region and the poorest for the northwest region. For the selected low-flow frequency equations for the northeast region, SEPs range from 32.4 to 48.4 percent for the spring equations and SEEs range from 56.4 to 73.8 percent for the fall equations (table 4). For the northwest region, SEEs range from 58.9 to 62.1 percent for the spring equations and from 83.2 to 109.4 percent for the fall equations (table 5). For the southern region, SEEs range from 43.2 to 64.0 percent for the spring equations and from 78.1 to 78.7 percent for the fall equations (table 6). The percentage of variation in the response variables explained by the explanatory variables (pseudo- $\mathrm{R}^{2}$ ) for the 18 spring and fall low-flow frequency equations developed for the three low-flow regions ranges from 91.0 to 98.1 percent (tables 4-6).

Of the six low-flow frequency equations developed for each region, the M30D10Y46 regression equations generally have the best predictive accuracy and the M1D10Y1012 equations generally have the poorest accuracy. The better predictive accuracies obtained for the spring equations (April through June), as compared to the fall equations (October through December), indicate less variation in base flows during the spring when compared to the fall. The natural variability of streamflow may be an important factor associated with the predictive accuracy of low-flow frequency regression equations. Estimation of streamflow statistics that have greater variability will have poorer predictive accuracies than estimation of statistics with less variability.

The regression equations presented in this report also should be used with caution in areas where low flows are affected by significant gains as a result of large springs or by significant losses as a result of sinkholes common to karst topography in areas underlain by limestone. The Paleozoic Plateau landform region (not shown) (Eash and Barnes, 2012) contains karst areas within the northeast region where low flows may occur with considerable spatial variability because of gaining or losing stream reaches. User judgment may be required to decide if an ungaged site in a karst area may be affected by significant gains or losses in low flow and if low-flow frequency regression estimates should be compared against streamgage data or other published data. The regression equations also should be used with caution for streams within the Mississippi River and Missouri River Alluvial Plains landform regions (not shown) (Eash and Barnes, 2012) because streamgage data representing these landform regions were not included in the development of the regression equations. If the equations are used at ungaged sites on regulated streams or on streams affected by water-supply and agricultural withdrawals, then the estimates will need to be adjusted by the amount of regulation or withdrawal to estimate the actual flow conditions.

The censoring threshold used to develop all of the leftcensored regression equations was set at $0.1 \mathrm{ft}^{3} / \mathrm{s}$ because of the uncertainty in measuring and estimating flows below $0.1 \mathrm{ft}^{3} / \mathrm{s}$. Thus, low-flow frequency estimates calculated from left-censored regression equations that are $0.1 \mathrm{ft}^{3} / \mathrm{s}$, or lower, should be reported as less than $0.1 \mathrm{ft}^{3} / \mathrm{s}$. For the northeast region, spring low-flow frequency estimates calculated from GLS regression equations that are lower than $0.1 \mathrm{ft}^{3} / \mathrm{s}$ also should be reported as less than $0.1 \mathrm{ft}^{3} / \mathrm{s}$ to maintain a consistent prediction-discharge-reporting limit for Iowa. Because the precision of response- and explanatory-variable data used to develop the equations was commonly limited to three significant figures, selected-statistic discharges estimated from the regression equations also should be limited to three significant figures.

For each of the three low-flow regions, the relations between observed and predicted discharges for M7D10Y0406 and M7D10Y1012 are shown in figures 3 and 4, respectively. The uncertainty of regression estimates can be seen graphically as a greater scatter of observed in relation to predicted points along the 1:1 line. For the southern region, a greater uncertainty is evident for the M7D10Y0406 and M7D10Y1012 discharges below the prediction-dischargereporting limit of $0.1 \mathrm{ft}^{3} / \mathrm{s}$. The point shown on figures 3 and 4 for the northeast region as map number 34 is the streamgage 05412100 Roberts Creek above Saint Olaf, Iowa (fig. 1). The Roberts Creek Basin is within a karst area of northeastern Iowa (Rowden and others, 1995) and as shown on figures 3 
and 4 and listed in table 1-1, the predicted M7D10Y0406 and M7D10Y1012 discharges for this streamgage are substantially greater than the observed M7D10Y0406 and M7D10Y1012 discharges indicating the possibility of a losing stream reach upstream from the site. A few other streamgages with some of the largest differences between predicted and observed M7D10Y0406 or M7D10Y1012 discharges are identified on figures 3 and 4 with labeled map numbers (fig. 1; table 1-1).

Table 7. Range of basin-characteristic values used to develop selected spring and fall low-flow frequency regression equations for unregulated streams in lowa.

[DRNAREA, geographic information system (GIS) drainage area; LC11CRPHAY, percent area of cultivated crops and hay from National Land Cover Database 2011 classes 81 and 82; DRNFREQ, drainage frequency; PRJULDEC10, mean July through December precipitation 1981-2010; Min, minimum; Max, maximum; M1D10Y0406, spring (April through June) 1-day mean low flow with a recurrence interval of 10 years; NA, not applicable; M7D10Y0406, spring (April through June) 7-day mean low flow with a recurrence interval of 10 years; M30D10Y46, spring (April through June) 30-day mean low flow with a recurrence interval of 10 years; M1D10Y1012, fall (October through December) 1-day mean low flow with a recurrence interval of 10 years; M7D10Y1012, fall (October through December) 7-day mean low flow with a recurrence interval of 10 years; M30D10YOD, fall (October through December) 30-day mean low flow with a recurrence interval of 10 years; SSURGOA, hydrologic soil type A; SSURGOD, hydrologic soil type D; SSURGOC, hydrologic soil type C; BSLDEM10M, average basin slope computed from 10-meter digital elevation model]

\begin{tabular}{|c|c|c|c|c|c|c|c|c|}
\hline \multicolumn{9}{|c|}{ Northeast region } \\
\hline \multirow{2}{*}{ Statistic } & \multicolumn{2}{|c|}{ DRNAREA } & \multicolumn{2}{|c|}{ LC11CRPHAY } & \multicolumn{2}{|c|}{ DRNFREO } & \multicolumn{2}{|c|}{ PRJULDEC10 } \\
\hline & Min & Max & Min & Max & Min & Max & Min & Max \\
\hline M1D10Y0406 & 1.40 & $6,508.34$ & 46.32 & 92.36 & 0.295 & 3.084 & NA & NA \\
\hline M7D10Y0406 & 1.40 & $6,508.34$ & 46.32 & 92.36 & 0.295 & 3.084 & NA & NA \\
\hline M30D10Y46 & 1.40 & $6,508.34$ & 46.32 & 92.36 & 0.295 & 3.084 & NA & NA \\
\hline M1D10Y1012 & 1.40 & $6,508.34$ & 46.32 & 92.36 & NA & NA & 2.89 & 3.26 \\
\hline M7D10Y1012 & 1.40 & $6,508.34$ & 46.32 & 92.36 & NA & NA & 2.89 & 3.26 \\
\hline M30D10YOD & 1.40 & $6,508.34$ & 46.32 & 92.36 & NA & NA & 2.89 & 3.26 \\
\hline & & & & west regi & & & & \\
\hline \multirow{2}{*}{ Statistic } & \multicolumn{2}{|c|}{ DRNAREA } & \multicolumn{2}{|c|}{ SSURGOA } & \multicolumn{2}{|c|}{ SSURGOD } & & \\
\hline & Min & Max & Min & Max & Min & Max & & \\
\hline M1D10Y0406 & 7.42 & $5,454.42$ & 0.014 & 7.886 & 0.000 & 11.302 & & \\
\hline M7D10Y0406 & 7.42 & $5,454.42$ & 0.014 & 7.886 & 0.000 & 11.302 & & \\
\hline M30D10Y46 & 7.42 & $5,454.42$ & 0.014 & 7.886 & 0.000 & 11.302 & & \\
\hline M1D10Y1012 & 7.42 & $5,454.42$ & 0.014 & 7.886 & 0.000 & 11.302 & & \\
\hline M7D10Y1012 & 7.42 & $5,454.42$ & 0.014 & 7.886 & 0.000 & 11.302 & & \\
\hline M30D10YOD & 7.42 & $5,454.42$ & 0.014 & 7.886 & 0.000 & 11.302 & & \\
\hline \multicolumn{9}{|c|}{ Southern region } \\
\hline \multirow{2}{*}{ Statistic } & \multicolumn{2}{|c|}{ DRNAREA } & \multicolumn{2}{|c|}{ SSURGOC } & \multicolumn{2}{|c|}{ SSURGOD } & \multicolumn{2}{|c|}{ BSLDEM10M } \\
\hline & Min & Max & Min & Max & Min & Max & Min & Max \\
\hline M1D10Y0406 & 2.59 & $7,784.50$ & 0.000 & 91.985 & 0.000 & 61.778 & NA & NA \\
\hline M7D10Y0406 & 2.59 & $7,784.50$ & 0.000 & 91.985 & 0.000 & 61.778 & NA & NA \\
\hline M30D10Y46 & 2.59 & $7,784.50$ & 0.000 & 91.985 & 0.000 & 61.778 & NA & NA \\
\hline M1D10Y1012 & 2.59 & $7,784.50$ & 0.000 & 91.985 & NA & NA & 1.10 & 12.30 \\
\hline M7D10Y1012 & 2.59 & $7,784.50$ & 0.000 & 91.985 & NA & NA & 1.10 & 12.30 \\
\hline M30D10YOD & 2.59 & $7,784.50$ & 0.000 & 91.985 & NA & NA & 1.10 & 12.30 \\
\hline
\end{tabular}



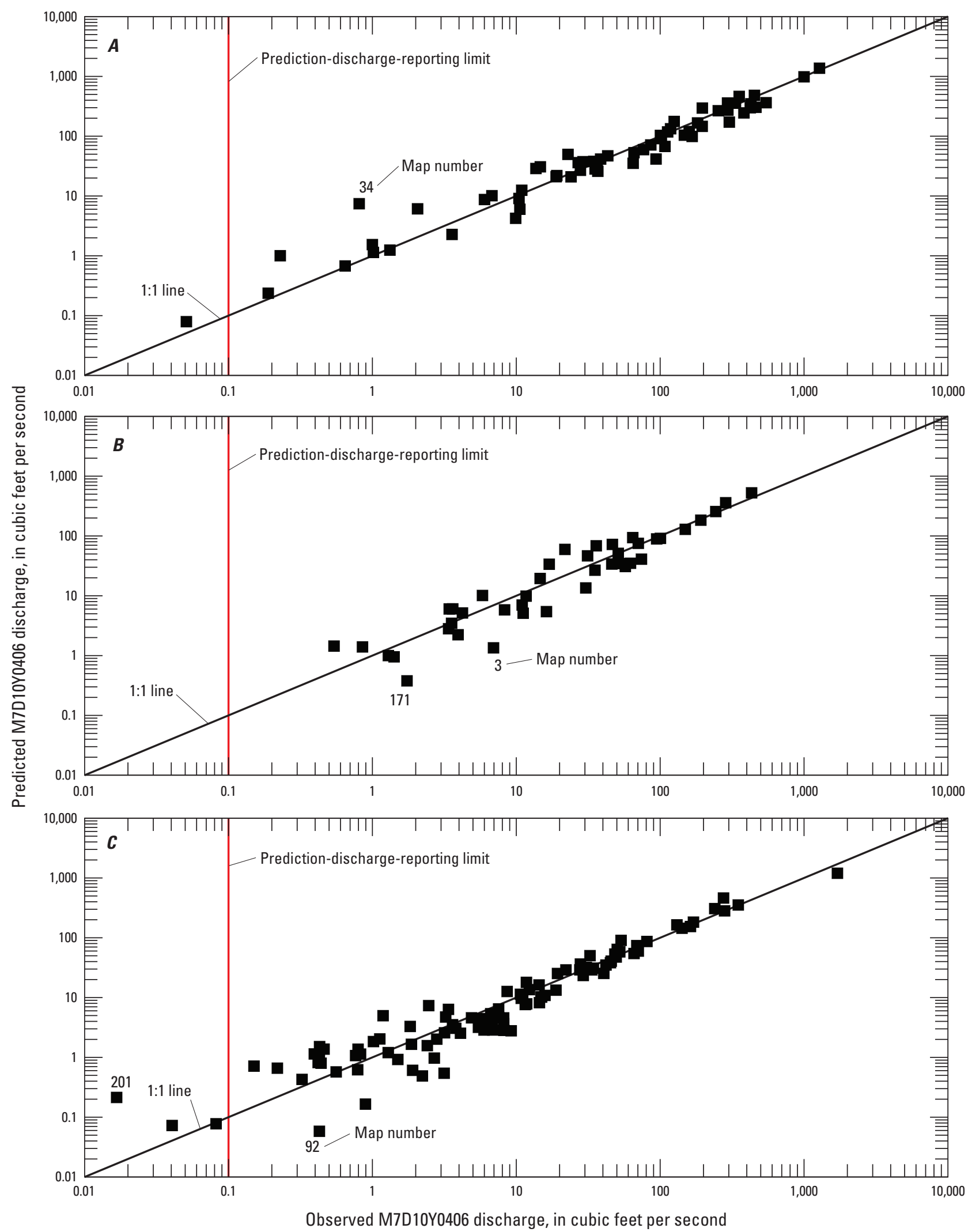

Figure 3. Relation between the spring (April through June) 7-day mean low-flow for a recurrence interval of 10 years (M7D10Y0406) discharges computed from observed streamflow and those predicted from regression equations for low-flow regions in lowa for $A$, northeast region; $B$, northwest region; and $C$, southern region, showing streamgages by map number (table 1-1) with some of the largest differences between predicted and observed discharges. 


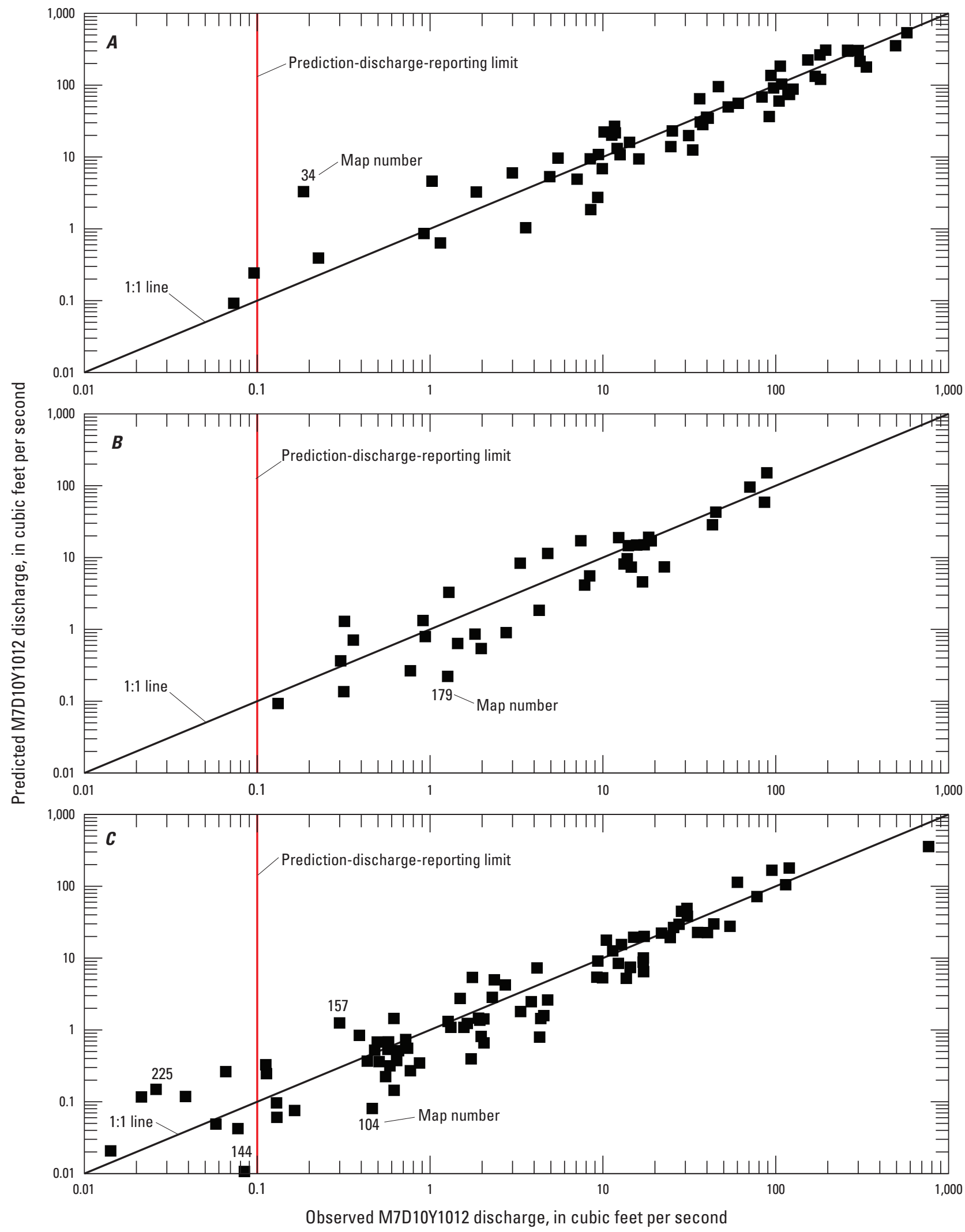

Figure 4. Relation between the fall (0ctober through December) 7-day mean low-flow for a recurrence interval of 10 years (M7D10Y1012) discharges computed from observed streamflow and those predicted from regression equations for low-flow regions in lowa for $A$, northeast region; $B$, northwest region; and $C$, southern region, showing streamgages by map number (table 1-1) with some of the largest differences between predicted and observed discharges. 


\section{Prediction Intervals}

Although regression equations presented in tables 4-6 can be used to estimate selected low-flow frequency statistics, the true values of the selected low-flow frequency statistics are unknown. A measure of the uncertainty associated with the regression estimate of a low-flow frequency statistic is the prediction interval. The prediction interval is the estimated discharge plus or minus a margin of error. The margin of error is directly related to the certainty with which the estimated discharge is known. A prediction interval is the probability that the true value of the estimated low-flow frequency statistic will be within the margin of error (Helsel and Hirsch, 2002). The prediction interval determines the range of discharge values estimated for selected statistics given a confidence level and the SEE or SEP. For a 90-percent prediction interval, the true low-flow frequency statistic has a 90 -percent probability of being within the margin of error. StreamStats (http://water. usgs.gov/osw/streamstats/) provides 90-percent prediction interval estimates as part of the computation of low-flow frequency statistics for ungaged stream sites in Iowa.

The following equation, modified from Tasker and Driver (1988), can be used for computing the 90-percent prediction interval of a low-flow frequency statistic for an ungaged site:

$$
\frac{Q}{T}<Q<Q T
$$

where

Q is the low-flow frequency discharge predicted for the ungaged site from the regression equation, and $T$ is computed as:

$$
T=10^{\left[t_{(a / 2, n-p)} S_{i}\right]}
$$

where

$$
\begin{gathered}
t_{(\alpha / 2, n-p)} \quad \text { is the critical value from the student's } \\
t \text {-distribution at alpha level } \alpha(\alpha=0.10 \text { for } \\
\text { 90-percent prediction intervals, critical } \\
\text { values may be obtained in many statistics } \\
\text { textbooks, Iman and Conover [1983], or } \\
\text { from the World Wide Web); } \\
n-p \quad \text { is the degrees of freedom with } n \text { streamgages } \\
\text { included in the regression analysis and } p \\
\text { parameters in the equation (the number of }
\end{gathered}
$$

explanatory variables plus one); and

$S_{i} \quad$ is the standard error of prediction for site $i$, and is computed as:

$$
S_{i}=\left[M E V+x_{i} U x_{i}^{\prime}\right]^{0.5}
$$

where

$$
\begin{gathered}
\text { MEV is the model error variance from GLS or left- } \\
\text { censored regression; } \\
x_{i} \quad \begin{array}{l}
\text { is the row vector for the streamgage } i, \\
\text { starting with the number 1, followed } \\
\text { by the logarithmic values of the basin } \\
\text { characteristics used in the regression; }
\end{array} \\
U \quad \text { is the covariance matrix for the seasonal } \\
\text { regression coefficients; and } \\
x_{i}^{\prime} \quad \text { is the matrix algebra transpose of } x_{i} \text { (Ludwig } \\
\text { and Tasker, 1993; Ries and Friesz, 2000). }
\end{gathered}
$$

Base 10 logarithm $(\log 10)$ transformations of the response variables were used to develop the three spring low-flow frequency equations for the northeast region (GLS equations in table 4). Therefore, equation 1 is directly applicable to compute 90 -percent prediction intervals for the spring low-flow frequency equations for the northeast region. In contrast, base $e$ or natural logarithm $(\ln )$ transformations of the response variables were used to develop all 15 left-censored RREs (tables 4-6). Therefore, the computation of 90-percent prediction intervals for these left-censored RREs requires the following modification of equation 2 to:

$$
T=e^{\left[t_{(a / 2, n-p)} S_{i}\right]}
$$

where

$\begin{aligned} e & \text { is the base of the natural logarithm, } \\ & \text { approximately equal to } 2.7183 ; \\ t_{(\alpha / 2, n-p)} & \text { is described in equation } 2 ; \\ n-p & \text { is described in equation } 2 ; \text { and } \\ S_{i} & \text { is described in equation } 2 .\end{aligned}$

Similar to the SEP, $S_{i}$ represents the sum of the model error and the sampling error for a single site $i$. The $x_{i} U x_{i}^{\prime}$ term in equation 3 also is referred to as the sampling error variance. The values of $t_{(\alpha / 2, \mathrm{n}-\mathrm{p})}$ and $U$ needed to determine prediction intervals for estimates obtained by the regression equations in tables 4-6 are presented in table 8 . 
Table 8. Values needed to determine the 90-percent prediction intervals for estimates obtained from regional regression equations using covariance matrices in lowa.

[ $t$, the critical value from Students t-distribution for the 90-percent probability used in equation 2; MEV, regression model error variance used in equation 3; $U$, covariance matrix as used in equation 3; M1D10Y0406, spring (April through June) 1-day mean low flow with a recurrence interval of 10 years; Intercept, $\mathrm{y}$-axis intercept of regression equation; $\log 10$, base 10 logarithm; DRNAREA, geographic information system (GIS) drainage area; LC11CRPHAY, percent area of cultivated crops and hay from National Land Cover Database 2011 classes 81 and 82; DRNFREQ, drainage frequency; M7D10Y0406, spring (April through June) 7-day mean low flow with a recurrence interval of 10 years; M30D10Y46, spring (April through June) 30-day mean low flow with a recurrence interval of 10 years; M1D10Y1012, fall (October through December) 1-day mean low flow with a recurrence interval of 10 years; ln, natural logarithm; PRJULDEC10, mean July through December precipitation 1981-2010; M7D10Y1012, fall (October through December) 7-day mean low flow with a recurrence interval of 10 years; M30D10YOD, fall (October through December) 30-day mean low flow with a recurrence interval of 10 years; SSURGOA, hydrologic soil type A; SSURGOD, hydrologic soil type D; SSURGOC, hydrologic soil type C; BSLDEM10M, average basin slope computed from 10-meter digital elevation model]

\begin{tabular}{|c|c|c|c|c|c|c|c|}
\hline \multirow[t]{2}{*}{$\begin{array}{c}\text { Response } \\
\text { variable }\end{array}$} & \multirow[t]{2}{*}{$t$} & \multirow[t]{2}{*}{ MEV } & \multicolumn{5}{|c|}{$\boldsymbol{U}$} \\
\hline & & & \multicolumn{5}{|c|}{ Northeast region } \\
\hline M1D10Y0406 & 1.6716 & 0.035 & & Intercept & $\log 10$ (DRNAREA) & $(\text { LC11CRPHAY) })^{-1}$ & DRNFREQ \\
\hline & & & Intercept & 0.06861304 & -0.00782208 & -2.13226270 & -0.00914123 \\
\hline & & & $\log 10$ (DRNAREA) & -0.00782208 & 0.00169461 & 0.13139149 & 0.00113048 \\
\hline & & & $(\mathrm{LC} 11 \mathrm{CRPHAY})^{-1}$ & -2.13226270 & 0.13139149 & 119.29041000 & -0.04768239 \\
\hline \multirow[t]{4}{*}{ M7D10Y0406 } & 1.6716 & 0.027 & & Intercept & $\log 10$ (DRNAREA) & (LC11CRPHAY) $^{-1}$ & DRNFREQ \\
\hline & & & Intercept & 0.05815076 & -0.00639711 & -1.79485390 & -0.00781088 \\
\hline & & & $\log 10$ (DRNAREA) & -0.00639711 & 0.00136318 & 0.10954126 & 0.00091759 \\
\hline & & & $(\mathrm{LC} 11 \mathrm{CRPHAY})^{-1}$ & -1.79485390 & 0.10954126 & 97.14397300 & -0.01985329 \\
\hline \multirow{4}{*}{ M30D10Y46 } & & & Intercept & 0.05032087 & -0.00548400 & -1.51576730 & -0.00652564 \\
\hline & & & $\log 10(\mathrm{DRNAREA})$ & -0.00548400 & 0.00101344 & 0.11090824 & 0.00074610 \\
\hline & & & $\left(_{\text {LC11CRPHAY) }}^{-1}\right.$ & -1.51576730 & 0.11090824 & 71.20494700 & 0.03587665 \\
\hline & & & DRNFREQ & -0.00652564 & 0.00074610 & 0.03587665 & 0.00246248 \\
\hline \multirow[t]{4}{*}{ M1D10Y1012 } & 1.6720 & 0.434544 & & Intercept & $\ln ($ DRNAREA) & $\ln (\mathrm{LC} 11 \mathrm{CRPHAY})$ & PRJULDEC10 \\
\hline & & & Intercept & 19.85965007 & -0.03021609 & -1.49056527 & -4.28698019 \\
\hline & & & $\ln$ (DRNAREA) & -0.03021609 & 0.00338453 & -0.00458385 & 0.00969964 \\
\hline & & & $\ln (\mathrm{LC} 11 \mathrm{CRPHAY})$ & -1.49056527 & -0.00458385 & 0.25462479 & 0.13600479 \\
\hline \multirow[t]{5}{*}{ M30D10YOD } & 1.6720 & 0.275835 & & Intercept & $\ln ($ DRNAREA) & $\ln (\mathrm{LC} 11 \mathrm{CRPHAY})$ & PRJULDEC10 \\
\hline & & & Intercept & 12.59683219 & -0.01951645 & -0.94468218 & -2.71956192 \\
\hline & & & $\ln$ (DRNAREA) & -0.01951645 & 0.00204856 & -0.00249271 & 0.00589020 \\
\hline & & & $\ln (\mathrm{LC} 11 \mathrm{CRPHAY})$ & -0.94468218 & -0.00249271 & 0.15985804 & 0.08745950 \\
\hline & & & PRJULDEC10 & -2.71956192 & 0.00589020 & 0.08745950 & 0.74671120 \\
\hline
\end{tabular}




\section{Methods for Estimating Selected Spring and Fall Low-Flow Frequency Statistics for Ungaged Stream Sites in lowa}

Table 8. Values needed to determine the 90-percent prediction intervals for estimates obtained from regional regression equations using covariance matrices in lowa.-Continued

$[t$, the critical value from Students t-distribution for the 90-percent probability used in equation 2; MEV, regression model error variance used in equation 3; $U$, covariance matrix as used in equation 3; M1D10Y0406, spring (April through June) 1-day mean low flow with a recurrence interval of 10 years; Intercept, $\mathrm{y}$-axis intercept of regression equation; $\log 10$, base 10 logarithm; DRNAREA, geographic information system (GIS) drainage area; LC11CRPHAY, percent area of cultivated crops and hay from National Land Cover Database 2011 classes 81 and 82; DRNFREQ, drainage frequency; M7D10Y0406, spring (April through June) 7-day mean low flow with a recurrence interval of 10 years; M30D10Y46, spring (April through June) 30-day mean low flow with a recurrence interval of 10 years; M1D10Y1012, fall (October through December) 1-day mean low flow with a recurrence interval of 10 years; ln, natural logarithm; PRJULDEC10, mean July through December precipitation 1981-2010; M7D10Y1012, fall (October through December) 7-day mean low flow with a recurrence interval of 10 years; M30D10YOD, fall (October through December) 30-day mean low flow with a recurrence interval of 10 years; SSURGOA, hydrologic soil type A; SSURGOD, hydrologic soil type D; SSURGOC, hydrologic soil type C; BSLDEM10M, average basin slope computed from 10-meter digital elevation model]

\begin{tabular}{|c|c|c|c|c|c|c|c|}
\hline $\begin{array}{c}\text { Response } \\
\text { variable }\end{array}$ & $t$ & MEV & & & $\boldsymbol{U}$ & & \\
\hline \multicolumn{8}{|c|}{ Northwest region } \\
\hline \multirow[t]{4}{*}{ M1D10Y0406 } & 1.6829 & 0.325926 & & Intercept & $\ln (\mathrm{DRNAREA})$ & SSURGOA & $\ln ($ SSURGOD + 1) \\
\hline & & & Intercept & 0.24002151 & -0.03464451 & -0.00486105 & -0.00382516 \\
\hline & & & $\ln$ (DRNAREA) & -0.03464452 & 0.00535693 & 0.00014328 & -0.00017182 \\
\hline & & & $\ln ($ SSURGOD + 1) & -0.00382516 & -0.00017182 & -0.00176098 & 0.01841006 \\
\hline \multirow[t]{3}{*}{ M7D10Y0406 } & 1.6829 & 0.300413 & & Intercept & $\ln (\mathrm{DRNAREA})$ & SSURGOA & $\ln ($ SSURGOD + 1) \\
\hline & & & Intercept & 0.21264537 & -0.03068344 & -0.00442748 & -0.00359995 \\
\hline & & & $\ln$ (DRNAREA) & -0.03068344 & 0.00475530 & 0.00012528 & -0.00014261 \\
\hline \multirow[t]{5}{*}{ M30D10Y46 } & 1.6829 & 0.298006 & & Intercept & $\ln (\mathrm{DRNAREA})$ & SSURGOA & $\ln ($ SSURGOD + 1) \\
\hline & & & Intercept & 0.18733324 & -0.02700443 & -0.00428565 & -0.00341832 \\
\hline & & & $\ln$ (DRNAREA) & -0.02700443 & 0.00421679 & 0.00011055 & -0.00015363 \\
\hline & & & SSURGOA & -0.00428565 & 0.00011055 & 0.00260402 & -0.00162944 \\
\hline & & & $\ln ($ SSURGOD + 1) & -0.00341832 & -0.00015363 & -0.00162944 & 0.01667028 \\
\hline \multirow[t]{3}{*}{ M1D10Y1012 } & 1.6839 & 0.787123 & & Intercept & $\ln$ (DRNAREA) & SSURGOA & $\ln ($ SSURGOD +1$)$ \\
\hline & & & Intercept & 0.92107223 & -0.13084840 & -0.01922336 & -0.01148612 \\
\hline & & & $\ln$ (DRNAREA) & -0.13084840 & 0.01948780 & 0.00133011 & -0.00027286 \\
\hline M7D10Y1012 & & & $\ln ($ SSURGOD + 1) & -0.01107737 & -0.00008190 & -0.00366743 & 0.04131790 \\
\hline \multirow[t]{5}{*}{ M30D10YOD } & 1.6839 & 0.525625 & & Intercept & $\ln$ (DRNAREA) & SSURGOA & $\ln (\mathrm{SSURGOD}+1)$ \\
\hline & & & Intercept & 0.52331686 & -0.07487628 & -0.01072457 & -0.00664591 \\
\hline & & & $\ln ($ DRNAREA) & -0.07487628 & 0.01130576 & 0.00060712 & -0.00027232 \\
\hline & & & SSURGOA & -0.01072457 & 0.00060712 & 0.00477211 & -0.00285348 \\
\hline & & & $\ln ($ SSURGOD + 1) & -0.00664591 & -0.00027232 & -0.00285348 & 0.03091760 \\
\hline
\end{tabular}


Table 8. Values needed to determine the 90-percent prediction intervals for estimates obtained from regional regression equations using covariance matrices in lowa.-Continued

[ $t$, the critical value from Students t-distribution for the 90-percent probability used in equation 2; MEV, regression model error variance used in equation 3; $U$, covariance matrix as used in equation 3; M1D10Y0406, spring (April through June) 1-day mean low flow with a recurrence interval of 10 years; Intercept, $\mathrm{y}$-axis intercept of regression equation; $\log 10$, base 10 logarithm; DRNAREA, geographic information system (GIS) drainage area; LC11CRPHAY, percent area of cultivated crops and hay from National Land Cover Database 2011 classes 81 and 82; DRNFREQ, drainage frequency; M7D10Y0406, spring (April through June) 7-day mean low flow with a recurrence interval of 10 years; M30D10Y46, spring (April through June) 30-day mean low flow with a recurrence interval of 10 years; M1D10Y1012, fall (October through December) 1-day mean low flow with a recurrence interval of 10 years; ln, natural logarithm; PRJULDEC10, mean July through December precipitation 1981-2010; M7D10Y1012, fall (October through December) 7-day mean low flow with a recurrence interval of 10 years; M30D10YOD, fall (October through December) 30-day mean low flow with a recurrence interval of 10 years; SSURGOA, hydrologic soil type A; SSURGOD, hydrologic soil type D; SSURGOC, hydrologic soil type C; BSLDEM10M, average basin slope computed from 10-meter digital elevation model]

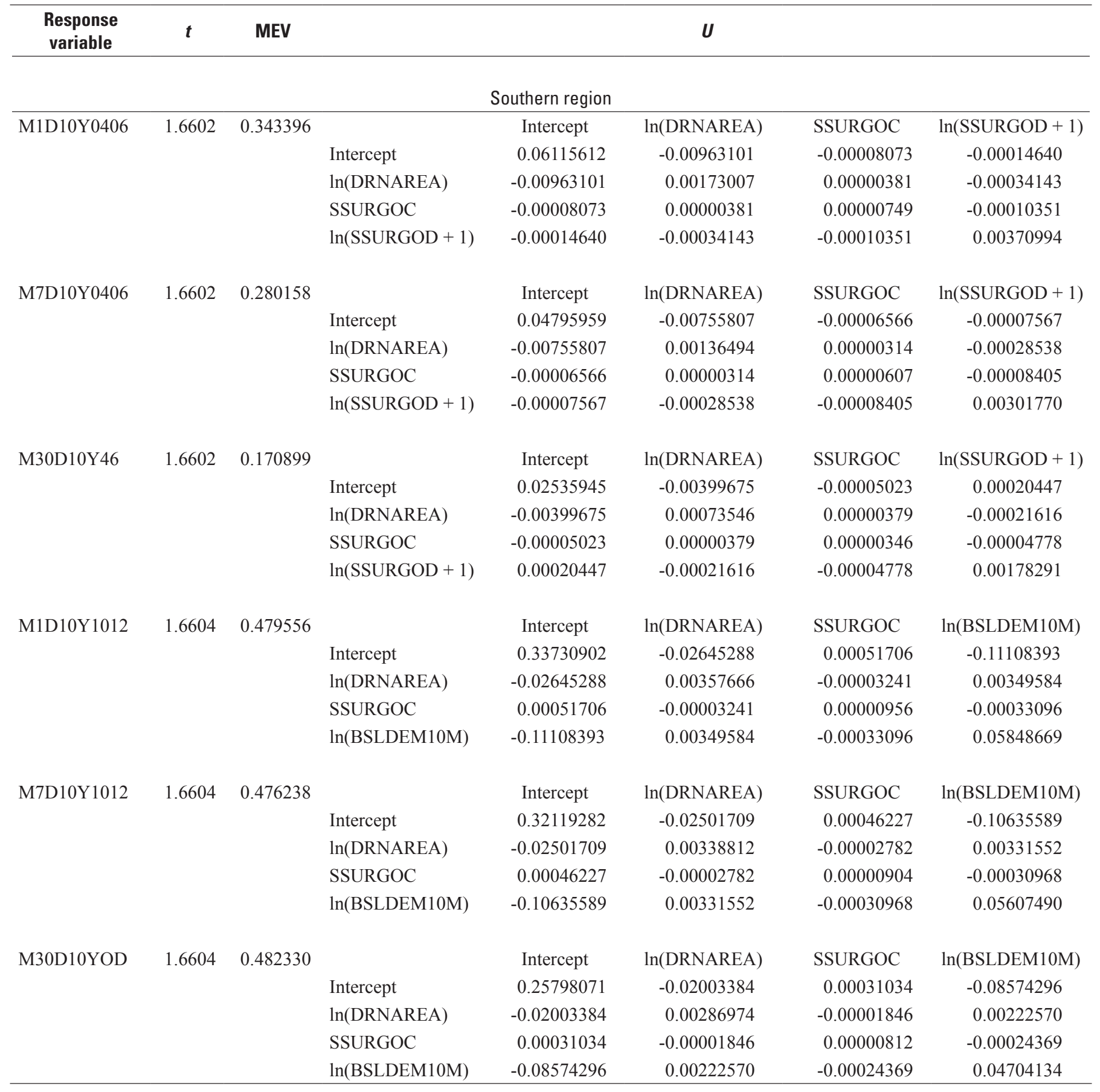




\section{Application of Regression Equations}

Methods for applying the RREs listed in tables 4-6 are described in the following examples:

\section{Example 1}

Example 1 is a calculation of M7D10Y0406 for a stream site in the northeast low-flow region. The location of the streamgage 05420560 Wapsipinicon River near Elma, Iowa (map number 45) is shown on figure 1. This drainage basin is within the northeast region. Using StreamStats, DRNAREA is measured as $96.44 \mathrm{mi}^{2}$, which is different from the published value (95.2 $\left.\mathrm{mi}^{2}\right)$; LC11CRPHAY is measured as 79.93 percent; and DRNFREQ is measured as 0.798 (table 1-1). Because all three basin-characteristic values are within the range of values listed in table 7, the GLS regression equation is applicable for estimating M7D10Y0406. The M7D10Y0406 GLS regression equation from table 4 is as follows:

$$
\begin{aligned}
& \text { M7D10Y0406 }=10^{-2.030} \text { DRNAREA }^{1.166} 10^{\left(47.02 \text { LC11CRPHAY }^{-1}\right)} 10^{(0.167 \text { DRNFREQ })} \\
& \text { M7D10Y0406 }=10^{-2.030} 96.44^{1.166} 10^{\left(47.0279 .93^{-1}\right)} 10^{(0.1670 .798)} \\
& \text { M7D10Y0406 }=10.1 \mathrm{ft}^{3} / \mathrm{s} \text {. }
\end{aligned}
$$

To calculate a 90-percent prediction interval for this M7D10Y0406 estimate using equation 1 , the $x_{i}$ vector is

$$
x_{i}=\left\{1, \log 10(96.44), 79.93^{-1}, 0.798\right\} \text {, }
$$

the model error variance (MEV) from table 8 is 0.027 , and the covariance matrix, $U$, is:

\begin{tabular}{c|cccc}
\hline \multicolumn{1}{c}{ Intercept } & Intercept & log10(DRNAREA) & \multicolumn{1}{c}{ LC11CRPHAY-1 } & \multicolumn{1}{c}{ DRNFREQ } \\
\cline { 2 - 5 } log10(DRNAREA) & 0.05815076 & -0.00639711 & -1.79485390 & -0.00781088 \\
LC11CRPHAY-1 & -0.00639711 & 0.00136318 & 0.10954126 & 0.00091759 \\
DRNFRE0 & -1.79485390 & 0.10954126 & 97.14397300 & -0.01985329 \\
\hline
\end{tabular}

Using matrix algebra, the product of $x_{i} U x_{i}^{\prime}$ is determined in two steps as follows: (1) by multiplying $x_{i}^{\prime}$ (the transpose of $x_{i}$ ) by the covariance matrix, $U$, to obtain $U x_{i}^{\prime}$ and (2) by multiplying $U x_{i}^{\prime}$ by $x_{i^{\prime}}$ In this example, the value of $x_{i} U x_{i}^{\prime}$ is 0.00620692 .

The standard error of prediction for this site as computed from equation 3 is

$S_{i}=[0.027+0.00620692]^{0.5}=0.182228$,

and $T$ from equation 2 is

$$
T=10^{(1.6716)(0.182228)}=2.0166,
$$

where the critical value $\left(t_{(\alpha / 2, n-p)}\right)$ from the student's $t$-distribution for the 90-percent prediction interval is 1.6716 (table 8 ).

The 90-percent prediction interval is estimated from equation 1 as

$10.1 / 2.0166<$ M7D10Y0406 < (10.1) (2.0166) or

$5.01 \mathrm{ft}^{3} / \mathrm{s}<$ M7D10Y0406 $<20.4 \mathrm{ft}^{3} / \mathrm{s}$. 


\section{Example 2}

Example 2 is a calculation of M30D10YOD for a stream site in the southern low-flow region. The location of the streamgage 06903700 South Fork Chariton River near Promise City, Iowa (map number 238) is shown on figure 1. This drainage basin is within the southern region. Using StreamStats, DRNAREA is measured as $169.47 \mathrm{mi}^{2}$, which is different from the published value $\left(168 \mathrm{mi}^{2}\right)$; SSURGOC is measured as 58.728 percent; and BSLDEM10M is measured as 6.031 percent (table 1-1). Because all three basin-characteristic values are within the range of values listed in table 7 , the left-censored regression equation is applicable for estimating M30D10YOD. The M30D10YOD left-censored regression equation from table 6 is as follows:

$$
\begin{aligned}
& \text { M30D10YOD }=\left(4.274 \times 10^{-4}\right)(\text { DRNAREA })^{1.424}(0.9623)^{\text {SSURGOC }}(\text { BSLDEM10M })^{1.165} \\
& \text { M30D10YOD }=\left(4.274 \times 10^{-4}\right)(169.47)^{1.424}(0.9623)^{58.728}(6.031)^{1.165} \\
& \text { M30D10YOD }=0.542 \mathrm{ft}^{3} / \mathrm{s} .
\end{aligned}
$$

To calculate a 90-percent prediction interval for this M30D10YOD estimate using equation 1 , the $x_{i}$ vector is

$$
x_{i}=\{1, \ln (169.47), 58.728, \ln (6.031)\} \text {, }
$$

the MEV from table 8 is 0.482330 , and the covariance matrix, $U$, is:

\begin{tabular}{c|cccc}
\hline \multicolumn{1}{c}{ Intercept } & Intercept & In(DRNAREA) & \multicolumn{1}{c}{ SSURGOC } & In(BSLDEM10M) \\
\cline { 2 - 5 } In(DRNAREA) & 0.25798071 & -0.02003384 & 0.00031034 & -0.08574296 \\
SSURGOC & -0.02003384 & 0.00286974 & -0.00001846 & 0.00222570 \\
In(BSLDEM10M) & 0.00031034 & -0.00001846 & 0.00000812 & -0.00024369 \\
\hline
\end{tabular}

Using matrix algebra, the product of $x_{i} U x_{i}^{\prime}$ is determined in two steps as follows: (1) by multiplying $x_{i}^{\prime}$ (the transpose of $x_{i}$ ) by the covariance matrix, $U$, to obtain $U x_{i}^{\prime}$ and (2) by multiplying $U x_{i}^{\prime}$ by $x_{i}$. In this example, the value of $x_{i} U x_{i}^{\prime}$ is 0.0146246 .

The standard error of prediction for this site as computed from equation 3 is

$S_{i}=[0.482330+0.0146246]^{0.5}=0.704950$,

and $T$ from equation 4 is

$T=e^{(1.6604)(0.704950)}=3.22360$,

where the critical value $\left(t_{(\alpha / 2, n-p)}\right)$ from the student's $t$-distribution for the 90 -percent prediction interval is 1.6604 (table 8).

The 90-percent prediction interval is estimated from equation 1 as

$0.542 / 3.22360<\mathrm{M} 30 \mathrm{D} 10 \mathrm{YOD}<(0.542)(3.22360)$ or

$0.168 \mathrm{ft}^{3} / \mathrm{s}<$ M30D10YOD $<1.75 \mathrm{ft}^{3} / \mathrm{s}$. 


\section{Weighted Drainage-Area Ratio Method to Estimate Selected Spring and Fall Low-Flow Frequency Statistics for Ungaged Stream Sites on Gaged Streams}

For ungaged sites on gaged streams in Iowa, a weighted drainage-area ratio (WDAR) method may provide better estimates of selected spring and fall low-flow frequency statistics than the RREs presented in this report (tables 4-6) when the drainage-area ratio (DAR) is between 0.5 and 1.4. This guidance is based on the results of testing the estimation accuracy for annual 7-day mean low-flow for a recurrence interval of 10 years (M7D10Y) for ungaged sites on gaged streams in Iowa in the previous study (Eash and Barnes, 2012). However, use of the WDAR method when the DAR is greater than 1.4 may produce negative values for some estimates (Eash and Barnes, 2012). Users should consider that errors of estimates (estimation accuracies) for ungaged sites cannot be quantified using the WDAR method and, therefore, should use the RREs presented in this report (tables 4-6) if errors of the estimates or 90-percent prediction intervals are needed.

\section{Example 3}

This example is a calculation of a WDAR estimate for the M1D10Y0406 statistic for a stream site in the northwest low-flow region. The location of streamgage 06605600 Little Sioux River at Gillette Grove, Iowa (map number 192) is shown on figure 1; this streamgage will be assumed to be an ungaged site for this example. The location of another streamgage 06605850 Little Sioux River at Linn Grove, Iowa (map number 193), which is downstream on the same stream, also is shown on figure 1; this site will be used as the streamgage in this example. This drainage basin is within the northwest region. The following is a list of five steps that are required to calculate an estimate for the WDAR method using equation 14 in Eash and Barnes (2012):

$$
Q_{\text {WDARu }}=Q_{r u}\left[R-\left(\frac{2(|\Delta D A|)(R-1)}{D A_{g}}\right)\right] .
$$

The first step is to calculate $Q_{r u}$, which is the RRE estimate for the ungaged site (map number 192). Using StreamStats to measure basin characteristics for the ungaged site, DRNAREA is measured as $1,352.03 \mathrm{mi}^{2}$, which is different from the published value $\left(1,334 \mathrm{mi}^{2}\right)$; SSURGOA is measured as 1.716 percent; and SSURGOD is measured as 0.461 percent (table 1-1). Because all three basin-characteristic values are within the range of values listed in table 7, the left-censored regression equation is applicable for estimating M1D10Y0406. The M1D10Y0406 left-censored regression equation from table 5 is as follows:

$$
\begin{aligned}
& \text { M1D10Y0406 }=\left(7.857 \times 10^{-4}\right)(\text { DRNAREA })^{1.527}(1.308)^{\text {SSURGOA }}(\text { SSURGOD }+1)^{-0.6233} \\
& \text { M1D10Y0406 }=\left(7.857 \times 10^{-4}\right)(1,352.03)^{1.527}(1.308)^{1.716}(0.461+1)^{-0.6233} \\
& \text { M1D10Y0406 }=59.4 \mathrm{ft}^{3} / \mathrm{s}=Q_{r u .}
\end{aligned}
$$

The second step is to calculate the DAR between the ungaged site and the streamgage to determine if the WDAR method is applicable for the ungaged site. The drainage area of the ungaged site $\left(1,352.03 \mathrm{mi}^{2}\right.$; map number 192) divided by the drainage area of the streamgage $\left(D A_{g}\right)$ in equation 14 in Eash and Barnes (2012) $\left(1,565.35 \mathrm{mi}^{2}\right.$; map number 193) produces a DAR of 0.864 . Because this DAR is between 0.5 and 1.4 , the WDAR method is applicable for the ungaged site. 
The third step is to calculate the absolute difference between the drainage area of the ungaged site and the drainage area of the streamgage $(|\Delta \mathrm{DA}|)$ as follows:

$$
\begin{aligned}
& |\Delta \mathrm{DA}|=1,352.03-1,565.35 \\
& |\Delta \mathrm{DA}|=213.32 \mathrm{mi}^{2} .
\end{aligned}
$$

The fourth step is to calculate the ratio $(R)$ of $Q_{o g}$, the M1D10Y0406 estimate from the observed streamgage record, and $Q_{r g}$, the M1D10Y0406 RRE estimate for the streamgage;

$$
\begin{aligned}
& R=Q_{o g} / Q_{r g} \\
& R=89.2 / 75.3 \\
& R=1.18 .
\end{aligned}
$$

Values for $Q_{o g}$ and $Q_{r g}$ are obtained from table 1-1 (map number 193).

The fifth step is to solve equation 14 in Eash and Barnes (2012) by calculating the WDAR M1D10Y0406 estimate for the ungaged site $\left(Q_{\text {WDARu }}\right)$ as follows:

$$
\begin{aligned}
Q_{\text {WDARu }} & =59.4[1.18-(2(213.32)(1.18-1) / 1,565.35)] \\
Q_{\text {WDARu }} & =67.2 \mathrm{ft}^{3} / \mathrm{s} .
\end{aligned}
$$

\section{StreamStats}

StreamStats is a USGS Web-based GIS application (http://water.usgs.gov/osw/streamstats/) that allows users to obtain streamflow statistics, drainage-basin characteristics, and other information for user-selected sites on streams. Users can select stream site locations of interest from an interactive map and can obtain information for these locations. If a user selects the location of a USGS streamgage, the user will get previously published information for the streamgage from a database. If a stream site location is selected where data are not available (an ungaged site), a GIS program will estimate information for the site. Additional information about StreamStats is presented in Eash and Barnes (2012).

All 18 regression equations presented in this report will be incorporated into the StreamStats application (http://water. usgs.gov/osw/streamstats/). StreamStats will then provide users the ability to estimate selected spring and fall low-flow frequency statistics and 90-percent prediction intervals for ungaged stream sites in Iowa using the 18 updated equations in this report.

\section{Summary}

Reliable estimates of low-flow statistics are essential for the effective management of water resources related to watersupply planning and management and for setting wastewatertreatment plant effluent limits and allowable pollutant loads to meet water-quality standards for irrigation, recreation, aquatic life, and wildlife conservation. In 2015, the U.S. Geological Survey led a statewide study in cooperation with the Iowa Department of Natural Resources to update and improve the accuracy of estimates of selected spring and fall low-flow frequency statistics for stream sites in Iowa.

Primary components of the study included (1) computing three selected spring low-flow frequency statistics at 241 continuous-record streamgages and three selected fall low-flow frequency statistics at 238 streamgages using the longest, most recent period of streamflow record through June 2014 without a significant trend; (2) measuring 63 basin characteristics for each of the 208 streamgages included in the fall season regression analyses and for an additional 3 streamgages for a total of 211 streamgages included in the spring season regression analyses; and (3) developing 18 regional regression equations (RREs) to estimate the six selected statistics at ungaged stream sites based on basin characteristics. Because only 9 years of fall streamflow record were available, 3 streamgages included in the computation of the spring statistics and the development of the spring regression equations were not included in the computation of the fall statistics and the development of the fall regression equations.

The Kendall's tau test was performed for the six number of consecutive days (N-day) time series at each streamgage (one test for each spring and fall $\mathrm{N}$-day record) because trends in the N-day data could introduce a bias into the selected spring and fall low-flow frequency analyses. Results of the Kendall's tau tests indicated statistically significant positive trends for 137 streamgages, and statistically significant negative trends for 1 streamgage, of the 241 streamgages tested when considering the period of record. A variable-lengthrecord approach to determine the longest period of record without a significant trend for all six N-day records using Kendall's tau trend analyses was selected for use for this study. Drainage areas of the streamgages used to develop the spring and fall RREs ranged from 1.4 to 7,785 square miles.

Methods described in this report for estimating selected spring and fall low-flow frequency statistics are applicable only to stream sites in Iowa that are not substantially affected by regulation, diversion, or urbanization and with basin characteristics within the range of those used to develop the equations. The RREs were developed for three selected spring (April through June) 1-, 7-, or 30-day mean low flow for a recurrence interval of 10 years (M1D10Y0406, M7D10Y0406, and M30D10Y46, respectively) and for three selected fall (October through December) 1-, 7-, or 30-day mean low flow for a recurrence interval of 10 years (M1D10Y1012, M7D10Y1012, and M30D10YOD, respectively).

The study area, which includes Iowa and adjacent areas within 50 miles of the Iowa border of neighboring States, was divided into three low-flow regions that were defined in a previous low-flow study. Regional regression analyses were used to relate physical and climatic characteristics of drainage basins to selected spring and fall low-flow frequency statistics for each of the three low-flow regions. 
Because a significant number of streamgages included in the development of RREs have estimates of zero flow calculated from observed streamflow for selected spring and fall low-flow frequency statistics, two types of regression analyses were performed to develop the final equations for the three low-flow regions-left-censored and generalized-least-squares (GLS) regression analyses. Left-censored regression analyses were performed to allow the use of a censoring threshold in the development of equations to estimate the three fall lowflow frequency statistics for all three low-flow regions and in the development of equations to estimate the three spring low-flow frequency statistics for the southern and northwest regions. Because streamgages in the northeast region did not have any estimates of zero flow calculated from observed streamflow for the selected spring low-flow frequency statistics, GLS multiple-linear regression analyses were used to develop the equations to estimate the three spring low-flow frequency statistics for the northeast region.

All 63 basin characteristics measured for each of the 211 streamgages included in the regression analyses were determined from digital databases using geographic information system (GIS) software. The eight basin characteristics used as explanatory variables in the final regression equations are as follows: three morphometric characteristics (GIS drainage area, average basin slope computed from a 10-meter digital elevation model, and drainage frequency), four pedologic/land-use characteristics (hydrologic soil type A, hydrologic soil type $\mathrm{C}$, hydrologic soil type $\mathrm{D}$, and percent area of cultivated crops and hay from National Land Cover Database 2011 classes 81 and 82), and one climatic characteristic (mean July through December precipitation 1981-2010). For the selected low-flow frequency equations for the northeast region, average standard errors of prediction range from 32.4 to 48.4 percent for the spring equations and average standard errors of estimate range from 56.4 to 73.8 percent for the fall equations. For the northwest region, average standard errors of estimate range from 58.9 to 62.1 percent for the spring equations and from 83.2 to 109.4 percent for the fall equations. For the southern region, average standard errors of estimate range from 43.2 to 64.0 percent for the spring equations and from 78.1 to 78.7 percent for the fall equations.

The GIS software is required to measure the basin characteristics included as explanatory variables in the regression equations. Low-flow frequency estimates calculated from censored regression equations that are 0.1 cubic foot per second $\left(\mathrm{ft}^{3} / \mathrm{s}\right)$, or lower, should be reported as less than $0.1 \mathrm{ft}^{3} / \mathrm{s}$. Selected spring low-flow frequency estimates calculated to be lower than $0.1 \mathrm{ft}^{3} / \mathrm{s}$ from GLS regression equations for the northeast region, also should be reported as less than $0.1 \mathrm{ft}^{3} / \mathrm{s}$ to maintain a consistent prediction-discharge-reporting limit for Iowa.
All 18 regression equations developed for this study will be included in the U.S. Geological Survey StreamStats Webbased GIS application. StreamStats will then provide users the ability to estimate selected spring and fall low-flow frequency statistics, drainage-basin characteristics, and 90-percent prediction intervals for ungaged stream sites in Iowa using the 18 updated equations in this report.

\section{References Cited}

Eash, D.A., and Barnes, K.K., 2012, Methods for estimating selected low-flow frequency statistics and harmonic mean flows for streams in Iowa: U.S. Geological Survey Scientific Investigations Report 2012-5171, 99 p., accessed April 11, 2016, at http://pubs.usgs.gov/sir/2012/5171/.

Eash, D.A., O’Shea, P.S., Weber, J.R., Nguyen, K.T., Montgomery, N.L., and Simonson, A.J., 2015, Statistical summaries of selected Iowa streamflow data through September 2013: U.S. Geological Survey Open-File Report 2015-1214, 18 p., accessed August 9, 2016, at http://dx.doi. org/10.3133/ofr20151214.

Eng, Ken, Chen, Yin-Yu, and Kiang, J.E., 2009, User's guide to the weighted-multiple-linear-regression program (WREG version 1.0): U.S. Geological Survey Techniques and Methods, book 4, chap. A8, 21 p., accessed April 11, 2016, at http://pubs.usgs.gov/tm/tm4a8/.

Environmental Systems Research Institute, Inc., 2014, ArcGIS Desktop: Release 10.3.1, Redlands, Calif., accessed April 11, 2016, at http://www.esri.com/.

Fischer, E.E., Melcher, N.B., and Kluesner, S.P., 1990, Statistical summaries of selected Iowa streamflow data through September 30, 1988: U.S. Geological Survey Open-File Report 90-170, 641 p., accessed June 13, 2016, at http:// pubs.usgs.gov/of/1990/0170/report.pdf.

Flynn, K.M.; Hummel, P.R.; Lumb, A.M.; and Kittle, J.L., Jr., 1995, User's manual for ANNIE, version 2, a computer program for interactive hydrologic data management: U.S. Geological Survey Water-Resources Investigations Report 95-4085, 211 p., accessed July 15, 2016, at http:// water.usgs.gov/software/SWSTAT/.

Funkhouser, J.E., Eng, K., and Moix, M.W., 2008, Low-flow characteristics and regionalization of low-flow characteristics for selected streams in Arkansas: U.S. Geological Survey Scientific Investigations Report 2008-5065, 161 p., accessed April 11, 2016, at http://pubs.usgs.gov/ $\operatorname{sir} / 2008 / 5065 /$. 
Griffis, V.W., and Stedinger, J.R., 2007, The use of GLS regression in regional hydrologic analyses: Journal of Hydrology, v. 344, p. 82-95, accessed April 11, 2016, at http://www.sciencedirect.com/science/article/pii/ S0022169407003848.

Helsel, D.R., and Hirsch, R.M., 2002, Statistical methods in water resources: U.S. Geological Survey Techniques of Water-Resources Investigations, book 4, chap. A3, 510 p., accessed April 11, 2016, at http://pubs.usgs.gov/twri/ twri4a3/\#pdf.

Homer, C.G., Dewitz, J.A., Yang, L., Jin, S., Danielson, P., Xian, G., Coulston, J., Herold, N.D., Wickham, J.D., and Megown, K., 2015, Completion of the 2011 National Land Cover Database for the conterminous United States-Representing a decade of land cover change information: Photogrammetric Engineering and Remote Sensing, v. 81, no. 5, p. 345-354, accessed April 11, 2016, at http://www.mrlc. gov/nlcd2011.php.

Iman, R.L., and Conover, W.J., 1983, A modern approach to statistics: New York, John Wiley and Sons, Inc., 497 p.

Interagency Advisory Committee on Water Data, 1982, Guidelines for determining flood flow frequency: U.S. Geological Survey, Office of Water Data Coordination, Bulletin 17B of the Hydrology Subcommittee, 28 p., plus appendixes, accessed April 11, 2016, at http://water.usgs.gov/osw/bulletin17b/bulletin_17B.html.

Iowa Department of Natural Resources and the U.S. Environmental Protection Agency, 2015, Iowa's 2014 list of Clean Water Act Section 303(d) impaired waters and integrated report: Iowa Department of Natural Resources Technical Fact Sheet, 7 p., accessed April 11, 2016, at http:// www.iowadnr.gov/Portals/idnr/uploads/watermonitoring/ impairedwaters/2014/Summary\%20for\%20Final $\% 20$ 2014\%20list\%20_\%20IR.pdf?ver=2015-11-06-100631-460.

Kroll, C.N., and Stedinger, J.R., 1996, Estimation of moments and quantiles using censored data: Water Resources Research, v. 32, no. 4, p. 1005-1012, accessed April 11, 2016, at http://www.esf.edu/ere/kroll/estimation_of moments_cencosred_data.pdf.

Kroll, C.N., and Vogel, R.M., 2002, Probability distribution of low streamflow series in the United States: Journal of Hydrologic Engineering, v. 7, no. 2, p. 137-146, accessed April 11, 2016, at http://ascelibrary.org/doi/pdf/10.1061/ (ASCE)1084-0699(2002)7\%3A2(137).

Kroll, C.N., Luz, Joana, Allen, Brad, Vogel, R.M., 2004, Developing a watershed characteristics database to improve low streamflow prediction: Journal of Hydrologic Engineering, v. 9, no. 2, p. 116-125, accessed April 11, 2016, at http://ascelibrary.org/doi/abs/10.1061/(ASCE)10840699(2004)9\%3A2(116).
Lara, O.G., 1979, Annual and seasonal low-flow characteristics of Iowa streams: U.S. Geological Survey Open-File Report 79-555, Iowa Natural Resources Council Bulletin, no. 13, 507 p., Plates 3 and 4 accessed April 11, 2016, at ftp://ftp.igsb.uiowa.edu/gis_library/IA_State/Hydrologic/ Surface_Waters/USGS_stream_low_flow_Plate3.html and ftp://ftp.igsb.uiowa.edu/gis_library/IA_State/Hydrologic/ Surface_Waters/USGS_stream_low_flow_Plate4.html.

Lins, Harry, 2005, Streamflow trends in the United States: U.S. Geological Survey Fact Sheet 2005-3017, 4 p., accessed April 11, 2016, at http://pubs.usgs.gov/ fs/2005/3017/.

Lorenz, D.L., 2014, smwrQW-R functions to support water-quality data analysis for statistical methods in water resources: U.S. Geological Survey R Archive Network, accessed April 11, 2016, at https://github.com/USGS-R/ smwrQW.

Ludwig, A.H., and Tasker, G.D., 1993, Regionalization of low-flow characteristics of Arkansas streams: U.S. Geological Survey Water-Resources Investigations Report 93-4013, 19 p., accessed June 28, 2016, at http://pubs.usgs.gov/ wri/1993/4013/report.pdf.

McCabe, G.J., and Wolock, D.M., 2002. A step increase in streamflow in the conterminous United States: Geophysical Research Letter, v. 29, p. 2185-2188, accessed April 11, 2016, at http://ks.water.usgs.gov/pubs/reports/dmw.grl.v29. html.

Miller, A.M, and Golladay, S.W., 1996, Effects of spates and drying on macroinvertebrate assemblages of an intermittent and a perennial stream: Journal of North American Benthological Society, v. 15, no. 4, p. 670-689, accessed April 11, 2016, at http://www.jstor.org/sici?sici=0887$3593 \% 28199612 \% 2915 \% 3$ A4\%3C670\%3AEOSADO $\% 3 \mathrm{E}$ 2.0.CO\%3B2-9\&.

National Climatic Data Center, 2012, Climate of Iowa: accessed April 11, 2016, at http://www.crh.noaa.gov/ images/dvn/downloads/Clim_IA_01.pdf.

Oschwald, W.R., Riecken, F.F., Dideriksen, R.I., Scholtes, W.H., and Schaller, F.W., 1965, Principal soils of Iowa: Ames, Iowa, Iowa State University, Department of Agronomy, Special Report no. 42, 77 p.

Prior, J.C., 1991, Landforms of Iowa: Iowa City, University of Iowa Press, p. 30-83, accessed July 15, 2016, at http://sustainableag.unl.edu/pdf/landformsofiowacari.pdf. 
Prior, J.C., Kohrt, C.J., and Quade, D.J., 2009, The landform regions of Iowa, vector digital data: Iowa Geological Survey, Iowa Department of Natural Resources, Iowa City, Iowa, accessed July 19, 2016, at ftp://ftp.igsb.uiowa.edu/ gis_library/ia_state/geologic/landform/landform_regions.zip and http://www.iowadnr.gov/Conservation/Wildlife-Stewardship/Iowa-Wildlife-Action-Plan/Landform-Regions-ofIowa.

PRISM Climate Group, 2016, 30-Year normal annual and monthly precipitation grids for the conterminous United States: accessed April 11, 2016, at http://prism.oregonstate. edu/normals/.

Ries, K.G., III, and Friesz, P.J., 2000, Methods for estimating low-flow statistics for Massachusetts streams: U.S. Geological Survey Water-Resources Investigations Report 00-4135, 81 p., accessed June 28, 2016, at http://pubs.usgs.gov/wri/ wri004135/.

Riggs, H.C., 1972, Low-flow investigations: U.S. Geological Survey Techniques of Water-Resources Investigations, book 4, chap. B1, 18 p., accessed April 11, 2016, at http:// pubs.usgs.gov/twri/twri4b1/index.html.

Rowden, R.D., Libra, R.D., and Hallberg, G.R., 1995, Surface water monitoring in the Big Spring Basin 1986-1992-A summary review: Iowa Department of Natural Resources Geological Survey Bureau Technical Information Series 33, 109 p., accessed April 11, 2016, at https://s-iihr34.iihr. uiowa.edu/publications/uploads/TIS-33.pdf.

Schilling, K.E., 2005, Relation of baseflow to row crop intensity in Iowa: Agriculture, Ecosystems and Environment, v. 105, nos. 1-2, p. 433-438, accessed April 11, 2016, at http://www.sciencedirect.com/science/article/pii/ $\mathrm{S} 0167880904001227$ ? $\mathrm{np}=\mathrm{y}$.

Schilling, K.E., and Libra, R.D., 2003, Increased baseflow in Iowa over the second half of the 20th century: Journal of American Water Resources Association, v. 39, no. 4, p. 851-860, accessed April 11, 2016, at http://onlinelibrary. wiley.com/doi/10.1111/j.1752-1688.2003.tb04410.x/pdf.

Smakhtin, V.U., 2001, Low flow hydrology-A review: Journal of Hydrology, v. 240, nos. 3-4, p. 147-186, accessed April 11, 2016, at http://www.sciencedirect.com/science/ article/pii/S0022169400003401.

Small, David, Islam, Shafiqul, and Vogel, R.M., 2006, Trends in precipitation and streamflow in the eastern U.S.-Paradox or perception?: Geophysical Research Letters, v. 33, LO3403, 4 p. , accessed April 11, 2016, at http://onlinelibrary.wiley.com/doi/10.1029/2005GL024995/full.
Soenksen, P.J., and Eash, D.A., 1991, Iowa floods and droughts, in National Water Summary 1988-89-Hydrologic events and floods and droughts: U.S. Geological Survey Water-Supply Paper 2375, p. 279-286, accessed April 11, 2016, at http://pubs.er.usgs.gov/publication/ wsp2375.

Southard, R.E., 2013, Computed statistics at streamgages, and methods for estimating low-flow frequency statistics and development of regional regression equations for estimating low-flow frequency statistics at ungaged locations in Missouri: U.S. Geological Survey Scientific Investigations Report 2013-5090, 28 p., accessed April 11, 2016, at http:// pubs.usgs.gov/sir/2013/5090/.

Tasker, G.D., and Driver, N.E., 1988, Nationwide regression models for predicting urban runoff water quality at unmonitored sites: Water Resources Bulletin, v. 24, no. 5, p. 10911101, accessed June 28, 2016, at http://onlinelibrary.wiley. com/doi/10.1111/j.1752-1688.1988.tb03026.x/pdf.

U.S. Department of Agriculture, Natural Resources Conservation Service, 2016, Geospatial data gateway: U.S. Department of Agriculture, accessed April 11, 2016, at https://gdg. sc.egov.usda.gov/.

U.S. Environmental Protection Agency, 2013, BASINS 4.1: U.S. Environmental Protection Agency, accessed April 11, 2016, at http://water.epa.gov/scitech/datait/models/basins/ index.cfm.

U.S. Environmental Protection Agency, 2015, Iowa's 2014 Integrated Report - Category 5- Impaired and TMDL needed: accessed July 15, 2016, at http://www.iowadnr.gov/ LinkClick.aspx?fileticket=OuA5EKTyeJ0\%3d\&portalid=3.

U.S. Geological Survey, 2016, National Water Information System-Web Interface: U.S. Geological Survey database, accessed April 11, 2016, at http://waterdata.usgs.gov/nwis/ sw.

Wagner, D.M., Krieger, J.D., and Veilleux, A.G., 2016, Methods for estimating annual exceedance probability discharges for streams in Arkansas, based on data through water year 2013: U.S. Geological Survey Scientific Investigations Report 2016-5081, 136 p., accessed August 11, 2016, at http://dx.doi.org/10.3133/sir20165081.

Wolock, D.M., Winter, T.C., and McMahon, G., 2004, Delineation and evaluation of hydrologic-landscape regions in the United States using geographic information system tools and multivariate statistical analyses: Environmental Management, v. 34, no. 1, p. S71-S88, accessed April 11, 2016, at http://dx.doi.org/10.1007/s00267-003-5077-9. 
Ziegeweid, J.R., Lorenz, D.L., Sanocki, C.A., and Czuba, C.R., 2015, Methods for estimating flow-duration curve and low-flow frequency statistics for ungaged locations on small streams in Minnesota: U.S. Geological Survey Scientific Investigations Report 2015-5170, 23 p., accessed April 11, 2016, at http://dx.doi.org/10.3133/sir20155170. 


\section{Appendix 1. Streamgage Information Included in this Study}

Table 1-1 lists a summary of streamgages included in this study. The map numbers listed in table 1-1 correspond to the map numbers listed for the streamgages shown in figure 1. Table 1-1 is presented as a Microsoft Excel ${ }^{\circledR}$ spreadsheet (http://dx.doi. $\operatorname{org} 10.3133 / \operatorname{sir} 20165111)$.

Table 1-1. Selected spring and fall low-flow frequency statistics, and basin characteristics for streamgages shown in figure 1.

Publishing support provided by:

Rolla Publishing Service Center

For more information concerning this publication, contact:

Director, USGS lowa Water Science Center

P.O. Box 1230

lowa City, IA 52244

(319) 337-4191

Or visit the lowa Water Science Center Web site at:

http://ia.water.usgs.gov/ 



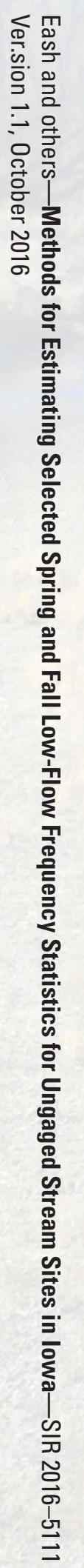

